the leadership, as trustees of the association, are entrusted with the discretion to determine if and how the association may respond to events or trends. McClain adds that a contextual element of peer association responses also contributes to the decisions around if and how APSA may respond. Jordan-Zachery suggests utilizing APSA's existing policies on diversity and inclusion on formulating statements. Price expresses support for how APSA has placed an emphasis on diversity, equity, and inclusion, but she and Berinsky note that not all members may agree with the actions taken in support of that commitment. Htun expresses concern about the broad scope of the screening document. Sides notes that a perspective from the small group discussion was that if APSA is committed to diversity, equity, and inclusion and can bring political science scholarship to bear on those topics, then it is possible that APSA should more proactively release statements on those topics rather than waiting for an event to make the topic relevant. Bleich asks if a more proactive stance would make APSA appear politicized. Oren notes that political science and politics are intertwined. In response to a remark by Ansell, Paulson replies that statements and letters are one of many ways in which APSA can communicate principles and values within the association's broader public affairs strategy. Price notes that Council can make statements because of the position of the Council in leading the association, and Demessie notes that silence as well as action can be perceived as a political act. A motion is made to adopt the updated Advocacy Policy; Price seconds and the motion passes with twenty-one ayes, two nays, and two abstentions.

\section{UPDATE ON ETHICS COMMITTEE REVISIONS TO THE ETHICS GUIDE}

Mealy introduces an update on the Ethics Committee's revisions to the Ethics Guide. She reports that the Ethics Committee is working as a whole committee as well as in working groups to review and revise the Ethics Guide. She notes that the Ethics Committee hopes to have a draft for review by the APSA staff and APSA legal counsel by summer
2021. The expectation is to have a final draft submitted for review by Council during the fall 2021 Council Meeting. Mealy notes that the Ethics Committee is also identifying any gaps in the Ethics Guide, particularly guidelines for online and virtual conduct.

\section{POLICY COMMITTEE UPDATES}

Vande Bunte provides updates on the work of the Meetings and Conferences Policy Committee. She reports that the committee has focused on working with related groups to allow them to reach the 35 -member threshold as well as providing guidance on the 2021 Annual Meeting.

Htun, chair of the Membership and Professional Development Policy Committee, provides updates on the work of the committee. She reports that the committee has focused on the member rebate policy and the member revocation policy.

Leal, chair of the Publications Policy Committee, provides updates on the work of the committee. He reports that the committee has focused on journal format, online access for journals, and open access.

Ansell, chair of the Public Engagement Policy Committee, provides updates on the work of the committee. He reports the committee has continued prior efforts to determine if APSA should issue guidelines for how to consider public engagement as part of the tenure and promotion process. He notes the committee is determining the role and purpose of a new standing committee. Paulson adds that the committee continues to discuss APSA's outreach strategy to members and the public.

C. Smith, member of the Teaching and Learning Policy Committee, provides updates on the work of the committee. He notes the committee is working on targeted videos about working and teaching at historically black colleges and universities. Additionally, the committee is working on maneuvering the Teaching and Learning Conference through the pandemic.

Box-Steffensmeier adjourns the meeting.

\title{
THE 2021 ORGANIZED SECTION AWARDS
}

\section{SECTION 1 : FEDERALISM \& INTERGOVERNMENTAL RELATIONS}

Martha Derthick Book Award

Conferred for the best book on federalism and intergovernmenta relations published at least 10 years ago that has made a lasting contribution to the study of federalism and intergovernmental relations.

Award Committee: Katrina Kosec (Chair), International Food Policy Research Institute; Jean-Paul Faguet, London School of Economics \& Political Science; Jacob Levy, McGill University Recipient: Jonathan Rodden, Stanford University Title: Hamilton's Paradox: The Promise and Peril of Fiscal Federalism. Cambridge University Press, 2005.

\section{Deil S. Wright Best Paper Award}

Conferred for the best paper in the field of federalism and intergovernmental relations presented at the previous year's annual meeting of the APSA.

Award Committee: Laura Evans (Chair), University of Washington; Julia Payson, New York University; Paula Clerici, Universidad de Buenos Aires
Recipients: Katrina Kosec, International Food Policy Research Institute and Tewodaj Mogues, International Monetary Fund Title: "Decentralization without Democracy." World Politics, 2020.

Daniel Elazar Distinguished Federalism Scholar Award Recognizes distinguished scholarly contributions to the study of federalism and intergovernmental relations.

Award Committee: Phil Rocco (Chair), Marquette University; Imke Harbers, University of Amsterdam; Connor Ewing, University of Missouri

Recipient: Kent Eaton, University of California, Santa Cruz

John Kincaid Best Article Award

Conferred on the author(s) of the best article published in Publius:

The Journal of Federalism in the previous year.

Award Committee: Allyson Benton (Chair), City University of London; Liesbet Hooghe, University of North Carolina; Jake Grumbach, University of Washington

Recipient: R. Kent Weaver, Georgetown University

Title: "Policy Dynamics in Federal Systems." Publius: The Journal of 
Federalism, 2020.

\section{SECTION 2: LAW AND COURTS}

\section{Best Graduate Student Paper Award}

This award (formerly the CQ Press Award) is given annually for the best paper in the field of law and courts written by a graduate student.

Award Committee: Charles Anthony (Tony) Smith (Chair), University of California, Irvine; Susan Achury, Miami University; Scott Barclay, Arizona State University; Lisa Holmes, University of Vermont; Jonathan Parent, LeMoyne College

Recipients: Nathan Carrington, Syracuse University and Claire Sigsworth, Syracuse University

Title: "Home-State Interest, Nationalism, and the Legitimacy of the Criminal Court."

\section{Teaching and Mentoring Award}

The Teaching and Mentoring Award recognizes innovative teaching and instructional methods and materials in law and courts.

The Teaching and Mentoring Award is supported by a generous contribution from the Division for Public Education of the American Bar Association.

Award Committee: Stephen Engel (Chair), Bates College; Cyril Ghosh, Wagner College; Lisa Hilbink, University of Minnesota; Joey Mello, DePaul University; Jamie Rowan, University of Massachusetts

Recipient: Carol Nackenoff, Swarthmore College

\section{Law and Courts Service Award}

The Law and Courts Service Award recognizes service to the section in the literal sense, as in service on committees and in leadership positions, as well as service within the Section, as in service to the profession within the field of law and courts in the form of archiving data, promoting infrastructure, representing the profession in the media, etc.

Award Committee: Keith Bybee (Chair), Syracuse University; Sara Benesh (Pashak), University of Wisconsin - Milwaukee; Jennifer Fredette, Ohio University; Lauren McCarthy, University of Massachusetts; Veronica Michel, City University of New York; Jason Pierceson, University of Illinois-Springfield

Recipient: Rebecca Reid, University of Texas - El Paso

\section{Best Conference Paper Award}

The Law and Courts Best Conference Paper Award (formerly the American Judicature Society Award) is given annually for the best paper on law and courts presented at the previous year's annual meeting.

Award Committee: Wendy Martinek (Chair), SUNY Binghamton; Elizabeth Chrun, McGill University; Lisa Conant, University of Denver; Edward Kammerer, Idaho State University; Dagmar Soennecken, York University

Recipients: Amanda Driscoll, Florida State University and Michael Nelson, Pennsylvania State University

Title: "The Minimal Costs of Court Curbing: Experimental Evidence from the United States."

\section{Best Journal Article Award}

This award recognizes the best journal article in the field of law and courts written by a political scientist and published during the previous calendar year.

Award Committee: Kathleen Sullivan (Chair), Ohio University; Traci Burch, Northwestern University; Tao Dumas, College of New Jersey; Maya Sen, Harvard University; Lisa Vanhalla, University
College London; Joshua Wilson, University of Denver

Recipient: Sarah Staszak, Princeton University

Title: "Privatizing Employment Law: The Expansion of Mandatory Arbitration in the Workplace." Studies in American Political Development 34 (2): 239-68.

Recipient: Whitney Taylor, San Francisco State University Title: "On the Social Construction of Legal Grievances: Evidence from Colombia and South Africa." Comparative Political Studies 53 (8): 1326-56.

\section{Herman Pritchett Award for Best Book}

The C. Herman Pritchett award is given annually for the best book on law and courts written by a political scientist and published the previous year.

Award Committee: Jeffrey Dudas (Chair), University of Connecticut; Taniesha Means, Vassar College; Paul Passavant, Hobart and William Smith Colleges; Julio Rios Figueroa Centro de Investigación y Docencia Económicas, Mexico City; Joanna Wuest, Princeton University

Recipient: Jinee Lokaneeta, Drew University

Title: The Truth Machines: Policing, Violence, and Scientific Interrogations in India. University of Michigan Press.

Recipient: Terri Peretti, Santa Clara University

Title: Partisan Supremacy: How the GOP Enlisted Courts to Rig America's Election Rules. University of Kansas Press.

Law and Courts Lasting Contribution Award Awarded annually to a book or journal article, 10 years old or older, that has made a lasting impression on the field of law and courts.

Award Committee: Carol Nackenoff (Chair), Swarthmore College; Eileen Braman, Indiana University; Jinee Lokaneeta, Drew University; Jerry Thomas, University of Wisconsin - Oshkosh; Lydia Tiede, University of Houston

Recipient: Ran Hirschl, University of Toronto

Title: Towards Juristocracy: The Origins and Consequences of the New Constitutionalism. Harvard University Press.

Law and Courts Lifetime Achievement Award

Given for a lifetime of significant scholarship, teaching and service to the Law and Courts field. Nominees must be political scientists who are at least 65 years of age or who have been active in the field for at least 25 years.

Award Committee: Susan Sterett (Chair), University of Maryland, Baltimore County; Rachel Cicowski, University of Washington; Tamir Moustafa, Simon Fraser University; Miriam Smith, York University; Art Ward, Northern Illinois University

Recipient: Leslie Goldstein, University of Delaware (Emerita)

\section{SECTION 3: LEGISLATIVE STUDIES}

\section{Alan Rosenthal Prize}

In the spirit of Alan Rosenthal's work, this prize is dedicated to encouraging young scholars to study questions that are of importance to legislators and legislative staff and to conduct research that has potential application to strengthening the practice of representative democracy. The prize is funded by the Trust for Representative Democracy of the National Conference of State Legislatures and the State Legislative Leaders Foundation.

Award Committee: Christopher J. Clark, University of North Carolina at Chapel Hill; Leslie A. Schwindt-Bayer, Rice University; Nils Ringe, University of Wisconsin

Recipient: Leah Stokes, University of California, Santa Barbara Title: Short Circuiting Policy: Interest Groups and the Battle over 
Clean Energy and Climate Policy in the American States. Oxford University Press, 2020.

\section{Carl Albert Dissertation Award}

The Carl Albert Dissertation Award is given annually for the best dissertation in legislative studies. Topics may be national or subnational in focus-on Congress, parliaments, state legislatures, or other representative bodies. The prize is funded by the Carl Albert Congressional Research and Studies Center at the University of Oklahoma. In addition to the cash prize associated with the award, winners are typically invited to guest lecture on the $\mathrm{OU}$ campus with travel expenses paid by the Carl Albert Center.

Award Committee: Lior Sheffer (Chair), Tel Aviv University; Sharece Thrower, Vanderbilt University; Danielle M. Thomsen, University of California, Irvine

Recipient: Erin Lauterbach, University of Virginia Title: "Punishments, Incentives, and Oversight: How Legislators Turn Preference into Policy." University of California, Riverside.

\section{CQ Press Award}

The CQ Press Award for the best paper on legislative studies presented at the previous year's (2020) APSA Annual Meeting.

Award Committee: Stefanie Bailer (co-chair), University of Basel; Oliver Huwyler (co-chair), University of Basel; Tomas Turner-Zwinkels (co-chair), University of Basel

Recipients: Mandi Eatough, University of Michigan and Jessica Preece, Brigham Young University

Title: "Toward a Fuller Accounting of Lawmaking: The Lawmaking Productivity Metric (LawProM)." Unpublished manuscript presented at the APSA Annual Meeting, 2019.

\section{Jewell-Loewenberg Prize}

Jewell-Loewenberg Prize for the best article in the Legislative Studies Quarterly in the previous year.

Award Committee: Mathias Wessel Tromborg (co-chair), Arhaus University; Hye Young You, New York University (co-chair); Michael Barber, Brigham Young University (co-chair)

Comparative Politics

Recipients: Raffaele Asquer, University of California, Los Angeles, Miriam A. Golden, European University Institute; Brian T. Hamel, University of California, Los Angeles

Title: "Corruption, Party Leaders and Candidate Selection: Evidence from Italy." Legislative Studies Quarterly 45(2): 291-325. American Politics

Recipient: Josh M. Ryan, Utah State University

Title: "Bicameralism and Minority-Party Influence on Legislative Development: Evidence from House Standing Committee Votes." Legislative Studies Quarterly 45(3): 365-396.

Subnational Politics

Recipients: Michael Peress, SUNY Stony Brook University and Yangzi Zhao, SUNY Stony Brook University

Title: "How Many Seats in Congress Is Control of Redistricting Worth?" Legislative Studies Quarterly, 45 (3): 433-468.

\section{Richard F. Fenno Jr. Prize}

The Richard F. Fenno, Jr. Prize is awarded to the best book in legislative studies published in the previous year. In the tradition of Professor Fenno's work, this prize is designed to honor work that is both theoretically and empirically strong. Moreover, this prize is dedicated to encouraging scholars to pursue new and different avenues of research in order to find answers to previously unexplored questions about the nature of politics.

Award Committee: Bryan D. Jones, University of Texas at
Austin; Sean M. Theriault, University of Texas at Austin; Michelle Whyman, Florida State University

Recipients: Beth Reingold, Emory University; Kerry L. Haynie, Duke University; Kirsten Widner, University of Tennessee

Title: Race, Gender, and Political Representation: Toward a More Intersectional Approach. Oxford University Press, 2020.

Honorable Mention: Jonathan Lewallen, University of Tampa Title: Committees and the Decline of Lawmaking in Congress. University of Michigan Press, 2020.

\section{Barbara Sinclair Legacy Award}

The Barbara Sinclair Legacy Award is designed to honor in the tradition of Professor Sinclair's body of work, recipients of this award will have focused on individual legislative behavior, institutional rules, or the role of party in shaping legislative politics. This award is also intended to recognize scholars who employ a range of methods in their research.

Award Committee: Wendy Schiller (Chair), Brown University; Michelle Taylor-Robinson, Texas A\&M University; Craig Volden, University of Virginia

Recipient: Kenneth Sheplse, Harvard University

\section{Emerging Scholar Award}

The Emerging Scholar award is designed to recognize a scholar who is no more than six years from the year of their $\mathrm{PhD}$ who has informed the study of legislative politics through innovative and rigorous scholarship.

Award Committee: Melinda Ritchie (Chair), University of California, Riverside; Alexander Bolton, Emory University; Taeko Hiroi, University of Texas at El Paso

Recipient: Ken Opalo, Georgetown University

\section{SECTION 4: PUBLIC POLICY}

\section{Aaron Wildavsky Enduring Contribution Award}

The Aaron Wildavsky Enduring Contribution Award is given for the best book or article published in the general area of public policy during the past twenty (20) to thirty (30) years. The book or article should have had a major impact on the field. This award carries a $\$ 500$ prize.

Award Committee: Suzanne Mettler, Cornell University; Joe Soss, University of Minnesota; Samuel Workman, University of Oklahoma

Recipient: Andrea Campbell, Massachusetts Institute of Technology

Title: How Policies Make Citizens. Princeton University Press, 2003.

\section{Best Paper on Public Policy Award}

The Best Paper on Public Policy Award recognizes the best paper on Public Policy given at the previous APSA Annual Meeting. This award carries a $\$ 500$ prize.

Award Committee: Ping Xu, University of Rhode Island; Jake Haselswerdt, University of Missouri; Gwen Arnold, University of California, Davis

Recipients: Jonas Meckling, University of California, Berkeley and Jonas Nahm, Johns Hopkins School of Advanced International Studies

Title: "Strategic State Capacity: How States Counter Opposition to Climate Policy." Unpublished manuscript presented at the APSA Annual Meeting, 2020.

Recipients: Natalia Bueno, Emory University; Felipe Nunes, Universidade Federal de Minas Gerais; Cesar Zucco, Fundacao Getulio Vargas 
Title:"Homeowners Unite? Homeownership, Values and Voice." Unpublished manuscript presented at the APSA Annual Meeting, 2020.

\section{Theodore J. Lowi Policy Studies Journal Best Article} Award

The Theodore J. Lowi Policy Studies Journal Best Article Award is given to recognize an article of particular distinction published at any time in Policy Studies Journal. This award carries a prize of $\$ 500$.

Award Committee: Domingo Morel, Rutgers University, Newark; Annelise Russell, University of Kentucky; Heather Rice, Slippery Rock University

Recipients: Sarah E. Anderson, University of California, Santa Barbara; Rob A. Deleo, Bentley University; Kristin O'Donovan, Wayne State University

Title: "Policy entrepreneurs, legislators, and agenda setting: information and influence." Policy Studies Journal, 48 (3): 587-611. .

\section{Excellence in Mentoring Award}

The Excellence in Mentoring Award has been established to recognize sustained efforts by a senior scholar to encourage and facilitate the career of emerging political scientists in the field of Public Policy. This award carries a $\$ 500$ prize.

Award Committee: Lael Kaiser, University of Missouri; Paru Shah, University of Wisconsin - Milwaukee; Christopher Witko, Pennsylvania State University

Recipient: Richard Hall, University of Michigan

\section{SECTION 5: POLITICAL ORGANIZATIONS AND PARTIES}

Samuel Eldersveld Career Achievement Award The Samuel Eldersveld Career Achievement Award recognizes a scholar whose lifetime professional work has made an outstanding contribution to the field

Award Committee: Eric Schickler (Chair), University of California, Berkeley; Corrine McConnaughy, Princeton University; John Ishiyama, University of North Texas

Recipient: Richard Hall, University of Michigan

\section{Leon Epstein Outstanding Book Award}

The Leon Epstein Outstanding book Award recognizes a book published in the last two calendar years that made an outstanding contribution to research and scholarship on political organizations and parties..

Award Committee: Hans Noel (Chair), Georgetown University; Zim Nwokora, Deakin University; Jennifer Nicoll Victor, George Mason University

Recipient: Nathan Kalmoe, Lovisiana State University Title: With Ballots and Bullets: Partisanship and Violence in the American Civil War. Cambridge University Press, 2020.

\section{POP/Party Politics Best Paper Award}

The POP/Party Politics Best Paper Award recognizes the best paper delivered on a Political Organizations and Parties-sponsored panel at the preceding APSA Annual Meeting.

Award Committee: Kira Sanbonmatsu (Chair), Rutgers University; Devin Fernandes, California State University, Chico; Anna Grzymala-Busse, Stanford University

Recipients: Wenyan Deng, Massachusetts Institute of Technology and Zeyu Chris Peng, Massachusetts Institute of Technology Title: "Latinization of Organized Labor and Democratic Immigration Positions." Unpublished manuscript presented at the APSA
Annual Meeting, 2020.

Jack Walker Journal Article Award

The Jack Walker Journal Article Award recognizes an article published in the last two calendar years that makes an outstanding contribution to research and scholarship on political organizations and parties.

Award Committee: Rob Boatright (Chair), Clark University; Zhao Li, Princeton University; Maraam A. Dwidar, Syracuse University

Recipient: Mathias Poertner, Texas A\&M University Title: "The Organizational Voter: Support for New Parties in Young Democracies." American Journal of Political Science, August, 2020.

\section{Emerging Scholars Award}

The Emerging Scholar Award is given to a scholar who has received his or her $\mathrm{PhD}$ within the last five years and whose career to date demonstrates unusual promise.

Award Committee: Seth Masket (Chair), University of Denver; Hye Young You, New York University; Julia Rezazadeh Azari, Marquette University

Recipient: Jake Grumbach, University of Washington

\section{SECTION 6: PUBLIC ADMINISTRATION}

\section{Herbert Kaufman Award}

The Herbert Kaufman Committee will select the best paper presented on a panel sponsored (or co-sponsored) by the Public Administration section at the APSA Annual Meeting each year. The section will follow APSA's guidance on what constitutes a "presented paper'-papers that were uploaded to the APSA conference paper site, hosted by SSRN, or posted/presented in a virtual or alternative form are eligible for the Kaufman award.

Award Committee: George Krause (Chair), University of Georgia; Anna Amirkhanyan, American University; Kenicia Wright, University of Central Florida

Recipients: Kelsey Shoub, University of South Carolina; Katelyn E. Stauffer, University of South Carolina; Miyeon Song, University of South Carolina

Tiłle: "Do Women Officers Police Differently? Evidence from Traffic Stops." Presented at the APSA Annual Meeting, 2020.

\section{Herbert A. Simon Book Award}

The Herbert Simon Book Award is given for significant contributions to public administration scholarship. Books with publication dates of 2015, 2016 and 2017 are eligible for the 2021 award. The books orientation may be qualitative, quantitative, empirical, interpretive, ethnographic, historical, archival, normative, or theoretical. However, textbooks, revised editions of previously published books, and edited volumes are not eligible.

Award Committee: Norma Riccucci (Chair), Rutgers University; Susan Miller, Arizona State University Simon Header, Pennsylvania State University

Recipients: Gary J. Miller, Washington University in St. Louis and Andrew B. Whitford, University of Georgia

Title: Above Politics: Bureaucratic Discretion and Credible Commitment. Cambridge University Press, 2016.

\section{Paul Volcker Junior Scholar Research Grant}

The APSA Organized Section for Public Administration invites applications and research proposals from junior scholars researching public administration issues affecting governance in the United States and abroad. Proposals will be judged on their potential 
to shed new light on important public administration questions, their scholarly and methodological rigor, and their promise for advancing practice and theory development. Individual grants are not renewable.

Award Committee: Frank Thompson (Chair), Rutgers University; Hongtao Yi, Ohio State University; Miyeon Song, University of South Carolina

Recipient: Chengxin $\mathrm{Xu}$, Seattle University

Title: "A Field Experiment on Discrimination against Immigrants in the US Health Care Market."

Recipients: Danbee Lee, University of Nebraska-Omaha and Minsung Micheal Kang, University of Nebraska-Omaha

Tiłle: "Bureaucratic Reputation, Whistle Blowing Management, and the Roles of Accountability Organizations."

\section{SECTION 7: CONFLICT PROCESSES}

\section{Best Paper Award}

This award is given annually for the best paper written by one or more untenured scholars (graduate students, post-docs, or faculty) and presented as part of a conflict processes sponsored panel or poster session at the previous annual meeting. Papers are eligible only if all authors are untenured at the time the paper is presented. Award Committee: Jun Koga Sudduth (Chair), University of Strathclyde; Kit Rickard, University College London; Laia Balcells, Georgetown University

Recipients: Michael Rubin, University of Connecticut; Daniel Arnon, Emory University; Richard McAlexander, University of Pennsylvania

Title: "Social Cohesion and Community Displacement in Armed Conflict. Evidence from Palestinian Villages in the 1948 War." International Relations.

\section{Lifetime Achievement Award}

The Lifetime Achievement award is given every other year in recognition of scholarly contributions that have fundamentally improved the study of conflict processes.

Award Committee: Burcu Savun (Chair), University of Pittsburgh; Kristin Bakke, University College London; Daniel Reiter, Emory University

Recipient: Paul Huth, University of Maryland

\section{J. David Singer Data Innovation Award}

The Singer Award recognizes projects which contribute to the enterprise of systematic data based work on conflict, international or domestic. The two primary criteria are impact and innovation. Projects with high impact influence the research of many others by providing datasetss or tools which are used widely in the field. Innovative projects change how we think about data in any number of ways, such as what we can collect as data, how we collect it, and how we analyze it. Projects which create public goods for the community of scholars who study conflict systematically are those that the award seeks to recognize.

Award Committee: Andrew Owsiak (Chair), University of Georgia; Jessica Maves Braithwaite, University of Arizona; Manuel Vogt, University College London

Recipients: Glenn Palmer, Pennsylvania State University; Charles Gochman, University of Pittsburgh ; Zeev Maoz, University of California, Davis; J. David Singer, University of Michigan; Daniel Jones, University of Michigan; Stuart Bremer, Pennsylvania State University; Faten Ghosn, University of Arizona; Matthew Lane, RAND Corporation; Mikaela Karstens, Pennsylvania State University; Michael Kenwick, Rutgers University; Vito D'Orazio, University of Texas at Dallas; Roseanne McManus, Pennsylvania
State University

Title: The Militarized Interstate Disputes Data

\section{SECTION 8: REPRESENTATION AND ELECTORAL SYSTEMS}

George H. Hallett Award

The George H. Hallett Award is given to the best book, which is at least ten years old, that has made a lasting contribution to the literature on representation and electoral systems.

Award Committee: Michael Saward, University of Warwick; Cynthia McClintock, George Washington University; Petia Kostadinova, University of Illinois-Chicago

Recipient: Alan I. Abramowitz, Emory University

Title: The Disappearing Center. Yale University Press, 2010.

\section{Lawrence Longley Award}

The Lawrence Longley Award is given to the best article on representation and electoral systems published in the previous year.

Award Committee: David Fortunato, University of California, San Diego; Carolina Plescia, University of Vienna; Meg Rincker, Purdue University Northwest

Recipients: Saad Gulzar, Stanford University; Nicholas Haas, Aarhus University; Benjamin Pasquale, Independent Researcher Title: "Does Political Affirmative Action Work, and for Whom? Theory and Evidence on India's Scheduled Areas." American Political Science Review 114 (4): 1230-46.

\section{Leon Weaver Award}

The Leon Weaver Award is given to the best paper presented at the previous APSA on a conference panel sponsored by the Representation and Electoral Systems Section.

Award Committee: Robert Moser, University of Texas at Austin; Stephanie Holmsten, University of Texas at Austin; Malliga Och, Idaho State University

Recipients: Amy Catalinac, New York University and Lucia Motolinia, New York University

Title: "Geographically-Targeted Spending in Mixed-Member Majoritarian Electoral Systems." Unpublished manuscript presented at the APSA Annual Meeting, 2020.

\section{SECTION 9: PRESIDENTS AND EXECUTIVE POLITICS}

The Richard E. Neustadt Best Book Award

The Richard E. Neustadt Award will be given for the best book on executive politics published during 2020.

Award Committee: George C. Edwards III (Chair), Texas A\&M University; Rebecca Dean, University of Texas at Arlington; lan Ostrander, Michigan State University; Joel Sievert, Texas Tech University

Recipients: Paul M. Collins, Jr., University of Massachusetts Amherst and Matthew Eshbaugh-Soha, University of North Texas Title: The President and the Supreme Court. Cambridge University Press, 2019.

\section{George C. Edwards III Dissertation Award}

The George C. Edwards III Dissertation Award is given for the best dissertation on executive politics completed and accepted during the previous two calendar years (January 1, 2019 - December $31,2020)$. The recipient will receive a $\$ 250$ award.

Award Committee: Shannon Bow O'Brien (Chair), University of Texas; Diane J. Heith, St. John's University; Jennifer Selin, University of Missouri; Adam McMahon, Rider University

Recipient: David R. Miller, East Tennessee State University Title: "All the President's Organized Interests." Dissertation, Wash- 
ington University in St. Louis, 2020.

\section{Founders Award Honoring Bert Rockman for Best} Paper

The Founders Award honoring Bert Rockman will be given for the best paper on executive politics authored by a PhD-holding scholar at the previous year's (2020) APSA Annual Meeting.

Award Committee: Anna Pluta (Chair), Rowan University; Katie Dunn Tenpas, Brookings Institution; Ted Ritter, Virginia Union University; Gary Hollibaugh, Jr., University of Pittsburgh

Recipient: Kevin M. Baron, Austin Peay State University Title: "Informal and Private: Veto Threats Over the Freedom of Information Act." Unpublished manuscript presented at the APSA Annual Meeting, 2020.

Founders Award honoring Erwin C. Hargrove for Best Graduate Student Paper

The Founders Award will be given for the best paper on executive politics presented by a Graduate Student at either the preceding year's APSA Annual Meeting or at any of the regional meetings in 2019 or 2020.

Award Committee: Michelle Belco (Chair), University of Houston; Gbemende Johnson, Hamilton College; Laurie L. Rice, Southern Illinois University, Edwardsville; Kevin Evans, Florida International University

Recipient: Nicholas G. Napolio, University of Southern California

Title: "Executive Coalition Building." Unpublished manuscript presented at the APSA Annual Meeting, 2020.

\section{The Legacy Award}

The Legacy Award will be given to a living author for a book, essay, or article, published at least 10 years prior to the award year that has made a continuing contribution to the intellectual development of the fields of presidency and executive politics. Award Committee: Gisela Sin (Chair), University of Illinois, Urbana-Champaign; Christina M. Kinane, Yale University; Sarah Burns, Rochester Institute of Technology; Jeffrey Crouch, American University

Recipient: James P. Pfiffner, George Mason University Title: The Strategic Presidency: Hitting the Ground Running, 2d. ed. Lawrence, KS: University Press of Kansas, 1996.

\section{PEP Career Service Award}

Every four years during a presidential election year, the division shall form a committee to give an award to recognize career service to the study of the presidency. The committee shall be chaired by the division's Vice President, and the criteria for the award shall be determined by the Steering Committee or its designees.

Award Committee: Brandon Rottinghaus (Chair), University of Houston; Karen Hult, Virginia Tech; Lori Cox Han, Chapman University; Mel Laracey, University of Texas at San Antonio Recipients: Martha Joynt Kumar, Towson University and Tom Cronin, Colorado College

\section{SECTION 10: POLITICAL METHODOLOGY}

\section{Career Achievement Award}

The career achievement is the highest honor bestowed by the Society and recognizes the foundational, distinguished and sustained contributions to the field and the Society made by the recipients over their careers.

Award Committee: Jeff Lewis, University of California, Los Angeles; Fred Boehmke, University of lowa; Michael Ward, Duke
University

Recipient: Larry Bartels, Vanderbilt University

\section{Emerging Scholar Award}

The Political Methodology Emerging Scholar Award honors a young researcher, within ten years of their degree, who is making notable contributions to the field of political methodology.

Award Committee: Sunshine Hillygus, Duke University; Burt Monroe, Pennsylvania State University; Tom Clark, Emory University

Recipient: Molly Roberts, University of California, San Diego

\section{Harold F. Gosnell Prize}

The Gosnell Prize for Excellence in Political Methodology is awarded for the best work in political methodology presented at any political science conference during the preceding year.

Award Committee: Anand Sokhey, University of Colorado; Skylar Cranmer, Ohio State University; Naoki Egami, Princeton University

Recipients: Avidit Acharya, Stanford University; Kirk Bansak, University of California, San Diego; Jens Hainmueller, Stanford University

Title:"Combining Outcome-Based and Preference-Based Matching: A Constrained Priority Mechanism."

Society for Political Methodology Poster Award Recognizes the best political methodology poster given at any political science conference in the preceding year.

Award Committee: John Londregan (Chair), Princeton University; Patrick Brandt, University of Texas at Dallas; Sarah Bouchat, Northwestern University; Thomas Gschwend, University of Mannheim; Charles Crabtree, Dartmouth College; Michael Bailey, Georgetown University; Erin Hartman, University of California, Los Angeles; Betsy Sinclair, Washington University in St. Louis Methods Category

Recipient: Melody Huang, University of California, Los Angeles Title: "Leveraging Observational Outcomes To Improve the Generalization Of Experimental Results."

Recipient: Nuannuan Xiang, University of Michigan

Title: "A Gaussian Process Model for Causal Inference with TSCS

Data."

Applications Category

Recipient: Erin Rossiter, Washington University in St. Louis Title: "The Consequences of Interparty Conversation on Outparty Affect and Stereotypes."

Recipient: Luwei Ying, Washington University, St. Louis Title: "Religiosity and Secularism: A Text-as-Data Approach to Recover Jihadist Groups' Rhetorical Strategies."

Faculty Poster

Recipient: Jay Goodliffe, Brigham Young University Title: "Using Latent Transition Analysis to Explain Donor Behavior."

\section{Statistical Software Award}

The Best Statistical Software Award recognizes individuals for developing statistical software that makes a significant research contribution.

Award Committee: Sarah Bouchat, Northwestern University; Graeme Blair, University of California, Los Angeles; Clayton Webb, University of Kansas; Nicholas Beauchamp, Northeastern University

Recipient: Ted Enamorado, Washington University in St Louis; Kosuke Imai, Harvard University; Ben Fifield, ACLU Legal Analyt- 
ics Group

Title: fastlink

Warren Miller Article Award

The Miller Prize for is awarded for the best work appearing in Political Analysis the preceding year.

Award Committee: Bear Braumoeller, Ohio State University; Alexandar Theodoridis, University of California, Merced; Patrick Brandt, University of Texas at Dallas; Jeff Gill, American University (ex officio)

Recipients: Reagan Mozer, Bentley University; Luke Miratrix, Harvard University; Aaron Russell Kaufman, New York University; L. Jason Anastasopoulos, University of Georgia

Title: "Matching with Text Data: An Experimental Evaluation of Methods for Matching Documents and of Measuring Match Quality." Political Analysis, 28(4): 445-468.

\section{Political Analysis Outstanding Reviewer Award} The Political Analysis Outstanding Reviewer Award recognizes individuals who have provided exemplary assistance to Political Analysis during the previous year. Outstanding Reviewers are those who provide excellent, timely and productive feedback for authors who have submitted manuscripts to Political Analysis. Outstanding Reviewers are also those who frequently review for the journal, and who provide the editors with productive advice about the submissions they review.

Award Committee: Jeff Gill, American University; Lonna R. Atkeson, University of New Mexico; D. Sunshine Hillygus, Duke University; Daniel Hopkins, University of Pennsylvania; Xun Pang, Tsinghua University; Betsy Sinclair, Washington University in St. Louis

Recipient: Melissa Rogers, Claremont Graduate University

\section{Excellence in Mentoring Award}

The Society for Political Methodology Excellence in Mentoring Award honors members of the Society who have demonstrated an outstanding commitment to mentoring and advising graduate and/or undergraduate students and, in particular, those from underrepresented groups.

Award Committee: David Darmofal, University of South Carolina; Amber Boydstun, University of California, Davis; Guillermo Rosas, Washington University in St. Louis

Recipients: Kosuke Imai, Harvard University and Rebecca Morton, New York University

\section{Box-Steffensmeier and Garcia ICPSR Summer Pro- gram Scholarship}

Award Committee: Mark Pickup, Simon Fraser University; Dave Peterson, lowa State University; Kelsey Shoub, University of South Carolina

Recipients: Michelle Irving, Rutgers University; Melina Much, University of California, Irvine; Ashley Sorensen, University of Minnesota; Marcus Vinícius De Sá Torres, Universidade Federal de Pernambuco; Linh Phan, University of California, Davis; Yu-Hsien Sung, University of South Carolina

\section{SECTION 11: RELIGION AND POLITICS}

\section{Hubert Morken Book Award}

The Hubert Morken Award is given for the best book dealing with religion and politics published within the previous year. The criteria for the award include the originality of the argument presented, quality of the research, innovative methods, readability of the text and the policy or practical implications of the scholarship.
Award Committee: David Buckley, University of Louisville; Laura Dudley Jenkins, University of Cincinnati; Eric McDaniel, University of Texas at Austin

Recipient: Alexander Thurston, Georgetown University Title: Jihadists of North Africa and the Sahel: Local Politics and Rebel Groups. Cambridge University Press, 2020.

Honorable Mention: John W. Compton, Chapman University Title: The End of Empathy: Why White Protestants Stopped Loving Their Neighbors. Oxford University Press, 2020.

Honorable Mentions: Amanda Hollis-Brusky, Pomona College and Joshua Wilson, University of Denver

Title: Separate but Faithful: The Christian Right's Radical Struggle to Transform Law and Legal Culture. Oxford University Press, 2020.

\section{Aaron Wildavsky Dissertation in Religion and Politics} Award

The Aaron Wildavsky Award recognizes the best dissertation in the field of religion and politics. Eligible dissertations have been defended in the last two years (2019 or 2020), and should make a distinctive contribution to the study of religion and politics, broadly understood.

Award Committee: Rina Williams, University of Cincinnati; Kristina Teater, University of Cincinnati; Guadalupe Tuñón, Princeton University; Peter Henne, University of Vermont

Recipient: Alexandra Blackman, Cornell University Title: "The Politicization of Faith: Settler Colonialism, Education, and Political Identity in Tunisia."

Honorable Mention: Alon Burstein, Hebrew University of Jerusalem

Tiłle: "Terrorizing God's Enemies: The Influence of Religion on Terror Group Activity."

\section{Ted Jelen Best Journal Article Award}

This award is presented for the best article published in Politics and Religion in the 2020 calendar year. There are no nominations for this award; every article published in the journal in 2020 is a candidate.

Award Committee: Günes Murat Tezcür, University of Central Florida; Kristin Fabbe, Harvard Business School; Jacob Neiheisel, State University of New York at Buffalo

Recipient: Ajay Verghese, Middlebury College

Title: "Taking Other Religions Seriously: A Comparative Survey of Hindus in India." Politics and Religion 13(3): 604-38.

Honorable Mentions: Andrew R. Lewis, University of Cincinnati; William D. Blake, University of Maryland, Baltimore County; Stephen T. Mockabee, University of Cincinnati; Amanda Friesen, Indiana University-Purdue University Indianapolis

Title: "American Constitutional Faith and the Politics of Hermeneutics." Politics and Religion 13 (1): 57-88.

\section{Weber Best Conference Paper in Religion and Politics} Award

Weber Best Paper in Religion and Politics Award recognizes the best paper dealing with religion and politics presented at the previous year's APSA Annual Meeting (2020).

Award Committee: Jonathan Agensky, Ohio University; Steven Brooke, University of Wisconsin; Laura Vinson, Lewis \& Clark College

Recipients: Tugba Bozcaga, Massachusetts Institute of Technology and Fotini Christia, Massachusetts Institute of Technology Title: "Imams and Businessmen: Islamist Service Provision in Turkey." Presented at the 2020 APSA Annual Meeting. 
Honorable Mention: Kikue Hamayotsu, Northern Illinois University

Title: "The Political Origins of Religious Regime Formation in Southeast Asia." Presented at the 2020 APSA Annual Meeting.

Susanne Hoeber Rudolph Outstanding Scholar in Religion and Politics Award

The Susanne Hoeber Rudolph Outstanding Scholar Award recognizes a scholar who has made outstanding contributions to the field of religion and politics. These contributions should be through a combination of excellent and widely influential scholarship, policy input/impact, public engagement, service, teaching, and mentorship.

Award Committee: Jocelyne Cesari, Harvard Divinity School; Joel Fetzer, Pepperdine University; Sultan Tepe, University of Illinois Chicago

Recipients: Paul Diupe, Denison University and Jonathan Fox, Bar-llan University

\section{SECTION 13: URBAN AND LOCAL POLITICS}

\section{Dennis Judd Best Book Awarc}

The Best Book Award recognizes the best book on urban politics published in the previous year.

Award Committee: Sarah Reckhow, Michigan State University; Lester Spence, Johns Hopkins University; David Kaufman, ETZ Zurich

Recipient: Adam Auerbach, American University

Title: Demanding Development: The Politics of Public Goods Provision in India's Urban Slums. Cambridge University Press, 2019.

Honorable Mention: Xuefei Ren, Michigan State University

Title: Governing the Urban in China and India: Land Grabs, Slum Clearance, and the War on Air Pollution. Princeton University Press, 2020.

Honorable Mention: Eleonora Pasotti, University of California, Santa Cruz

Title: Resisting Redevelopment: Protest in Aspiring Global Cities. Cambridge University Press, 2020.

\section{Best Dissertation Award}

The Best Dissertation Award is given annually for the best dissertation on urban politics accepted in the previous year.

Award Committee: Eleonora Pasotti, University of California, Santa Cruz; Christopher Warshaw, George Washington University; Akira Drake Rodriguez, University of Pennsylvania

Recipient: Marshail Malik, Harvard University

Title: "The Microfoundations of Identity Politics in Pakistan's Megacity"

Honorable Mention: Tanu Kumar, College of William and Mary

Title: "How Welfare Shapes Beneficiaries' Political and Economic Behavior: Evidence From Two Programs in India."

\section{Best Paper Award}

Urban Affairs Review is sponsoring a $\$ 250$ award for the Best Paper in Urban, Local, or Regional Politics presented at the American Political Science Association conference.

Award Committee: Philip Ashton, University of Illinois, Chicago; Mirya Holman, Tulane University; Mary Alice Haddad, Wesleyan University

Recipients: Rafaelle Bazurli, Ca' Foscari University, Venice and David Kaufmann, Swiss Federal Institute of Technology

Title: "Asylum Policy-Making in European Cities."
Norton Long Career Achievement Award

The Norton Long Career Achievement Award is presented annually to a scholar who has made distinguished contributions to the study of urban politics over the course of a career through scholarly publication, the mentoring of students, and public service.

Award Committee: Margaret Weir, Brown University; Rodney Hero, Arizona State University; John Mollenkopf, City University of New York

Recipient: Terry Moe, Stanford University

\section{Susan Clarke Young Scholars' Award}

The Susan Clarke Young Scholars' award recognizes scholars who completed their PhD within the last three years (or are ABDs) and submitted a paper proposal for the 2020 APSA meeting to the 2020 Division Chairs.

Award Committee: Vlad Kogan, Ohio State University; Meg Rithmire, Harvard University; Christopher Gore, Ryerson University Recipients: Maria Carreri, University of California, San Diego and Tanu Kumar, College of William and Mary

\section{Clarence Stone Scholar Award}

The Clarence Stone Scholar Award recognizes up to two young scholars who are making a significant contribution to the study of urban politics. The award is to be given to up to two post-PhD scholars who are in their career (pre-tenure, or recently advanced within the last 3 years).

Award Committee: Jessica Trounstine, University of California, Merced; Anne Pitcher, University of Michigan; Kimberly Johnson, New York University

Recipients: Eduardo Moncada, Barnard College and Katherine Einstein, Boston University

\section{SECTION 15: SCIENCE, TECHNOLOGY \& ENVIRONMENTAL POLITICS}

Don K. Price Award

The Don K. Price Award is given for the best book on science, technology, and politics published in the last year.

Award Committee: Chris Weible (Chair), University of Colorado Denver; Louise Comfort, University of Pittsburgh; Kristin Taylor, Wayne State University

Recipient: Leah Stokes, University of California, Santa Barbara Title: Short-Circuiting Policy: Interest Groups and the Battle Over Clean Energy and Climate Policy in the American States. Oxford University Press, 2021.

\section{Lynton Keith Caldwell Prize}

The Lynton Keith Caldwell Prize is given for the best book on environmental politics and policy published in the past three years.

Award Committee: Liz Shanahan (Chair), Montana State University; Eve Bratman, Franklin \& Marshall College; Rebecca Bromley-Truijillo, Christopher Newport University Recipient: Kimberly K. Smith, Carleton College Title: The Conservation Constitution, The conservation movement and constitutional change 1870-1930. University Press of Kansas, 2019.

\section{Virginia M. Walsh Dissertation Award}

The Virginia Walsh Dissertation Award is named in honor of a young scholar who tragically passed away last year, is given for the best dissertations in the field of science, technology and environmental politics. Nominations should include full dissertation.

Award Committee: Ramiro Berardo (Chair), Ohio State University; Leah Stokes, University of California, Santa Barbara; Jared 
Finnegan, Princeton University

Recipient: Alexander Gard-Murray, University of Oxford Title: "Splitting the Check: A Political Economy of Climate Change Policy"

Paul A. Sabatier Best Conference Paper Award The Paul A. Sabatier Best Conference Paper Award is given for the best paper on science, technology, and environmental politics presented at the previous year's APSA Annual Meeting.

Award Committee: Elizabeth Koebele (Chair), University of Nevada, Reno; Erik Merkley, University of Toronto; Hongtao Yi, Ohio State University

Recipients: Saad Bulzar, Stanford University; Apoorva Lal, Stanford University; Benjamin Pasquale, Independent Researcher Title: "Representation and Forest Conservation: Evidence from India's Scheduled Areas." Paper Presented at the 2020 APSA Annual Meeting.

\section{The Elinor Ostrom Career Achievement Award}

The Elinor Ostrom Career Achievement Award is given to an individual in recognition of their lifetime contribution to the study of science, technology, and environmental politics.

Award Committee: Matto Mildenberger, University of California, Santa Barbara; Aseem Prakash, University of Washington; Deserai Crow, University of Colorado, Denver

Recipient: Peter May, University of Washington

\section{The Evan Ringquist Best Paper Award}

The Best Paper Award is given for the best paper published in a relevant journal in the last two years. Relevant journals include political science, public administration, public policy, interdisciplinary environmental science, and science and technology studies journals.

Award Committee: Sarah Anderson (Chair), University of California, Santa Barbara; Aditya Das Gupta, University of California, Merced; Geoboo Song, University of Arkansas

Recipient: Amanda Kennard, Stanford University Title: "The Enemy of My Enemy: When Firms Support Climate Change Regulation." International Organization. 74 (2): 187-221.

\section{The Emerging Young Scholars Award}

The Emerging Young Scholar Award is given in recognition of a researcher, within ten years of their $\mathrm{PhD}$ degree, who is making notable contributions to the field of science, technology, and environmental politics.

Award Committee: Rachel Krause, University of Kansas; Mark Buntaine, University of California, Santa Barbara; Edella Schlager, University of Arizona

Recipients: Patrick Bayer, University of Strathclyde and Gwen Arnold, University of California, Davis

\section{SECTION 16: WOMEN, GENDER, AND POLITICS RESEARCH}

Best Dissertation Prize

The Best Dissertation Award is given for the best dissertation on women and politics completed and successfully defended in the previous calendar year.

Award Committee: Anne Runyan, University of Cincinnati; Isabel Castillo, Pontificia Universidad Católica de Chile; Catherine Wineinger, Western Washington University

Recipient: Kelly Kaitlin-Thompson, Purdue University Title: "There is Power in a Plaza: Social Movements, Democracy, and Spatial Politics."
Best Paper Award

The Best Paper Award is given for the best paper on women and politics at the previous year's APSA conference. Any individual can nominate a paper for the award, including self-nominations. In addition, all papers presented in the Women and Politics Research Section and posted to the APSA conference paper website will be considered nominated.

Award Committee: Colleen Shogan, The David M. Rubenstein Center, White House Historical Association, and Women's Suffrage Centennial Commission; Christine M. Slaughter, University of California, Los Angeles; Elena Gambino, Rutgers University

Recipients: Rebecca Sanders, University of Cincinnati and Laura Dudley Jenkins, University of Cincinnati

Title: "Control, Alt, Delete: Patriarchal Populist Attacks on International Women's Rights."

The Okin-Young Award in the Feminist Political Theory The Okin-Young Award in Feminist Political Theory is jointly given by the Section, Foundations of Political Theory, and the Women's Caucus for Political Science. The award commemorates the scholarly, mentoring, and professional contributions of Susan Moller Okin and Iris Marion Young to the development of the field of feminist political theory. This annual award recognizes the best paper on feminist theory published in an English language academic journal during the previous calendar year. Papers are considered by self-nomination or nomination by other individuals.

Award Committee: Mehwish Sarwari, Buffalo State University; Menaka Philips, Tulane University; Judith Grant; Ohio University

Recipient: Jemima Repo, Newcastle University

Title: "Feminist Commodity Activism: The New Political Economy of Feminist Protest."

Best Paper on Race and Intersectionality Award Best Paper on Intersectionality, to be co-sponsored with the Race, Ethnicity, and Politics Section. This award is for the best paper addressing intersectionality presented at the previous year's annual meeting. The scope of the award recognizes the roots of intersectional analysis in a critical analysis of the lived experiences of women of color, while also allowing for a more expansive reading of identity politics that takes into account multiple subjectivities and experiences, both within and outside the United States. Nomination Instructions: Self-nominations and nominations by others are welcome. To be considered for this award, a copy of the article should be sent electronically to each committee member by the deadline set by the Section.

Award Committee: Nadia E. Brown, Georgetown University; Kenicia Wright, University of Central Florida; Jamil Scott, Georgetown University; Ivy Cargile, California State University, Bakersfield

Recipient: Sally Nuamah, Northwestern University Title: "Public Perceptions of Black Girls and their Punitive Consequences."

\section{Public Engagement Award}

Public engagement award: An annual award to recognize the exemplary public-facing work of political scientists in the field of Women, Gender, and Politics. This award seeks to recognize significant efforts to serve a local community/do outreach on women, gender and politics, or efforts to diffuse knowledge beyond the classroom, and to make a social/political difference. While all faculty are eligible for this award, we especially welcome nominations of permanent and non-permanent faculty with teaching loads of 3-3 and above. 
Award Committee: Lorna Bracewell, Flagler College; Alice Kang, University of Nebraska-Lincoln; Kanisha Bond, Binghamton University

Recipient: Karen L. Owen, University of West Georgia

\section{Best Article Award}

Best article published in Politics \& Gender: An annual award to recognize the best article published in our section journal, Politics \& Gender, during the previous year.

Award Committee: Kristin Williams, Clark University; Andrew Reynolds, Princeton University; Danielle Thomsen, University of California, Irvine

Recipient: Jennifer Shore, University of Mannheim

Title: "Singled Out or Drawn In? Social Policies and Lone Mothers' Political Engagement."

\section{SECTION 17: FOUNDATIONS OF POLITICAL THEORY}

\section{David Easton Award}

The David Easton Award is given for a book that broadens the horizons of contemporary political science by engaging issues of philosophical significance in political life through any of a variety of approaches in the social sciences and humanities.

Award Committee: John McCormick, University of Chicago; James Martel, San Francisco State University; Lori Marso, Union College

Recipient: Cressida Heyes, University of Alberta

Title: Anaesthetics of Experience. Duke University Press, 2020.

Honorable Mention: Mahmood Mandani

Title: Neither Settler Nor Native. Harvard University Press, 2020.

\section{First Book Award}

The First Book Award is given for a first book by a scholar in the early stages of his or her career in the area of political theory or political philosophy.

Award Committee: Elizabeth Anker, George Washington University; Lida Maxwell, Boston University; Yves Winter, McGill University

Recipient: Kyong-Min Son, University of Delaware

Title: The Eclipse of the Demos: The Cold War and the Crisis of Democracy before Neoliberalism. University Press of Kansas, 2020.

Honorable Mention: Sara Rushing, Montana State University Title: The Virtues of Vulnerability. Oxford University Press, 2020.

The Okin-Young Award in the Feminist Political Theory The Okin-Young Award in Feminist Political Theory is jointly given by the Section, Foundations of Political Theory, and the Women's Caucus for Political Science. The award commemorates the scholarly, mentoring, and professional contributions of Susan Moller Okin and Iris Marion Young to the development of the field of feminist political theory. This annual award recognizes the best paper on feminist theory published in an English language academic journal during the previous calendar year. Papers are considered by self-nomination or nomination by other individuals.

Award Committee: Mehwish Sarwari, Buffalo State University; Menaka Philips, Tulane University; Judith Grant; Ohio University

Recipient: Jemima Repo, Newcastle University

Title: "Feminist Commodity Activism: The New Political Economy of Feminist Protest."

\section{SECTION 18: INFORMATION TECHNOLOGY AND POLITICS}

Best Dissertation in the APSA Information Technology and Politics Section

The Best Dissertation Award recognizes the best dissertation in the area of Information Technology and Politics defended April 1 or later of the previous calendar year (after April 1, 2020 for the 2021 award).

Award Committee: Xu Xu, Stanford University; Abigail Coplin Vassar College; Matthew Placek, University of South Carolina Upstate

Recipient: Josh Simons, Harvard University

Title: "Democracy against Prediction: Citizen Rule in the Age of Machine Learning."

\section{Best Paper in the APSA Information Technology and} Politics Section

Best paper presented in information technology and politics at the previous year's APSA Annual Meeting.

Award Committee: Michael M. Franz, Bowdoin College; Gregory J. Martin, Stanford University; Travis N. Ridout, Washington State University

Recipients: Annelise Russell, University of Kentucky and Whitney Hua, University of Southern California

Title: "Tweeting Red: Angry Emotional Appeals in Congress." Unpublished manuscript presented at the 2020 APSA Annual Meeting.

\section{Best Article in the APSA Information Technology and} Politics Section

Best article published in Information Technology and Politics published in the previous calendar year (i.e., 2020 for 2021's award call; must have appeared in an issue - articles that are published as online first should be considered for the year in which they are published in their final version).

Award Committee: Jennifer M. Larson, Vanderbilt University; Sharon Meraz, University of Illinois; Stephen Meserve, Northern Arizona University

Recipients: Guy Grossman, University of Pennsylvania; Macartan Humphreys, Columbia University and WZB Berlin, Gabriella Sacramone-Lutz, Columbia University

Title: "Information Technology and Political Engagement: Mixed Evidence from Uganda." Journal of Politics 82(4), 2020.

\section{Best Book in the APSA Information Technology and Politics Section}

The Best Book Award recognizes the best book in the area of Information Technology and Politics. The contest is limited to books published in the previous calendar year.

Award Committee: Nils Weidmann, University of Konstanz; Espen Geelmuyden Rod, Uppsala University; Molly Roberts, University of California, San Diego

Recipient: Rachel K. Gibson, University of Manchester Title: When the Nerds Go Marching in: How Digital Technology Moved from the Margins to the Mainstream of Political Campaigns. Oxford University Press, 2020.

\section{Best Student Paper in the APSA Information Technolo-} gy and Politics Section

Best student paper presented in information technology and politics at the previous year's APSA.

Award Committee: Heather Hughes, University of Haifa; Chris Barrie, Edinburgh University; Kira Pronin, University of Pittsburgh Recipients: Katharina Heger, Leipzig University and Christian P. Hoffmann, Leipzig University 
Title: "Women's Online Political Participation: Empowerment Through a Feminist Identity." Presented at the 2020 APSA Annual Meeting.

\section{SECTION 19: INTERNATIONAL SECURITY}

Kenneth N. Waltz Dissertation Award The Kenneth N. Waltz Dissertation Award is a yearly award given by the International Security section to the best defended dissertation on the study of international security and arms control.

Award Committee: Sumit Ganguly (Chair), Indiana University; Brian Blankenship, University of Miami; Roseanne McManus, Pennsylvania State University; Peter Henne, University of Vermont; Daniel Gressang, Embry Riddle Aeronautical University

Recipient: Renanah Miles Joyce, Massachusetts Institute of Technology and Harvard University

Title: "Exporting Might and Right: Great Power Security Assistance and Developing Militaries." 2020.

Joseph J. Kruzel Memorial Award for Public Service The Joseph Kruzel Memorial Award for Distinguished Public Service is awarded to a scholar with a distinguished career in national security affairs both as an academic and a public servant. It is given to memorialize Joseph Kruzel, a security studies scholar and policy official who was killed while on a diplomatic mission to Bosnia.

Award Committee: Gale Mattox (Chair), United States Naval Academy; Wayne Bert; Bruce Jentleson, Duke University; David A. Cooper, US Naval War College; Meredith Reid Sarkees, Global Women's Leadership in International Security

Recipient: Susan Shirk, University of California, San Diego

\section{Best International Security Article}

The International Security organized section of Best Article Award seeks to recognize the best peer-reviewed articles in the field of international security and security studies each year.

Award Committee: Charles Boehmer (Chair), University of Texas at El Paso; James McCormick, lowa State University; Ryuta Ito, Keio University; Erica De Bruin, Hamilton University; Jackie Kerr, Stanford University

Co-Recipient: Daniel Altman, Georgia State University

Title: "The Evolution of Territorial Conquest After 1945 and the Limits of the Territorial Integrity Norm." International Organization, 74 (3): 490-522.

Co-Recipient: Annette Idler, University of Oxford

Title: "The Logic of Illicit Flows In Armed Conflict Explaining Variation in Violent Nonstate Group Interactions in Colombia." World Politics, 72 (3): 335-376.

\section{Best International Security Book by Non-Tenured Fac-} ulty

Awarded to best international security themed book published in 2020 by a scholar who has not been awarded tenure.

Award Committee: Ryan Burke (Chair), United States Air Force Academy; Sumit Ganguly, Indiana University; Brian J Phillips, University of Essex; Katherine Barbieri, University of South Carolina

Recipient: Barbara Elias, Bowdoin College

Title: Why Allies Rebel: Defiant Local Partners in Counterinsurgency Wars. Cambridge University Press, 2020.

\section{SECTION 20: COMPARATIVE POLITICS}

Luebbert Book Prize

Awarded annually for the best book published in the field of comparative politics.

Award Committee: Dawn Teele (Chair), University of Pennsyl- vania; Jason Brownlee, University of Texas at Austin; Jana Morgan, University of Tennessee; Lucan Way, University of Toronto

Recipient: Rachel Brulé, Boston University

Title: Women, Property, and Power. Cambridge University Press, 2020.

Luebbert Article Prize

Awarded annually for the best article published in the field of comparative politics during 2019 and 2020.

Award Committee: Gabrielle Kruks-Wisner (Chair), University of Virginia; Carl Henrik Knutsen, University of Oslo; David Doyle, University of Oxford

Recipient: Daniel Gingerich, University of Virginia

Title: "Ballot Reform as Suffrage Restriction: Evidence from Brazil's Second Republic." American Journal of Political Science, 63 (4): 920-35.

\section{Sage Paper Prize}

Awarded to the best paper in comparative politics presented at the 2020 meeting of the American Political Science Association.

Award Committee: John Gerring (Chair), University of Texas at Austin; Junyan Jiang, Columbia University; Milada Vachudova, University of North Carolina at Chapel Hill

Recipients: Nikhar Gaikwad, Columbia University; Erin Lin, Ohio State University; Noah Zucker, Columbia University

Title: "Genocide and the Gender Gap in Political Representation."

\section{Lijphart/Przeworski/Verba Dataset Award}

Awarded annually to a publicly-available dataset in the field of comparative politics. Nominations (including self-nominations) should be submitted directly to the committee. Please include a nomination letter, instructions on accessing the dataset, and any publications or documents describing the dataset.

Award Committee: George Tsebelis (Chair), University of Michigan; Jennifer Bussell, University of California, Berkeley; Ryan Carlin, Georgia State University

Recipients: Jacob Nyrup, Aarhus University and University of Oxford and Stuart Bramwell, University of Oxford

Title: "Who governs?"

\section{Theda Skocpol Prize for Emerging Scholars}

Awarded to a scholar up to ten years post-PhD whose work has made impactful empirical, theoretical and/or methodological contributions to the study of comparative politics.

Award Committee: Evelyne Huber (Chair), University of North Carolina at Chapel Hill; Peter Hall, Harvard University; Yuen Yuen Ang, University of Michigan

Recipient: Amy Erica Smith, lowa State University and Noam Lupu, Vanderbilt University

\section{SECTION 21: EUROPEAN POLITICS AND SOCIETY}

Best Book Award

The Best Book Award is given for the best book on European politics and society published in 2020.

Award Committee: Christopher Way, Cornell University; Aina Gallego, Institut de Barcelona d' Estudis Internacionals; Darius Orston, University of Toronto

Recipients: Isabela Mares, Yale University and Lauren Young, University of California, Davis

Title: Conditionality and Coercion: Electoral Clientelism in Eastern Europe. Cambridge University Press, 2019.

Honorable Mentions: Stefanie Walter, University of Zurich; Nils Redeker, University of Zurich; Ari Ray, European University Institute 
Title: The Politics of Bad Options: Why the Eurozone's Problems Have Been So Hard to Resolve. Oxford University Press, 2020.

\section{Ernst B. Haas Best Dissertation Award}

The Ernst B. Haas Best Dissertation Award is given for the best dissertation on European politics and society filed in 2020.

Award Committee: Seth Jolly, Syracuse University; Alison Johnston, Oregon State University; Andreas Wiedemann, Princeton University

Recipient: Laura Jakli, University of California, Berkeley Title: "Estimating Extremism: New Measures of Extreme Party Preferences and Issue Positions?"

Honorable Mention: Diane Bolet, London School of Economics Title: "'All Politics is Local': How Local Context Explains Radical Right Voting."

Honorable Mention: Jan P. Vogler, University of Virginia Title: "The Political Economy of Public Bureaucracy: The Emergence of Modern Administrative Organizations."

\section{Best Article Award}

The Best Article Award is given for the best article dealing with European politics and society published in 2020.

Award Committee: Sergi Pardos-Prado, University of Glasgow; Alexandra Cirone, Cornell University; Tarik Abou-Chadi, University of Zurich

Recipients: Nan Zhang, Max Planck Institute of Collective Goods and Melissa Lee, Princeton University

Title: "Literacy and State-Society Interactions in Nineteenth-Century France." American Journal of Political Science, 64 (6): 1001 1016.

Honorable Mentions: Francesc Amat, University of Barcelona, IPERG-UB; Carles Boix, Princeton University, IPERG-UB; Jordi Muñoz, University of Barcelona, IPERG-UB; Toni Rodon, Universitat Pompeu Fabra

Title: "From Political Mobilization to Electoral Participation: Turnout in Barcelona in the 1930s." Journal of Politics 82(4).

\section{Best Paper Award}

The Best Paper Award is given for the best paper presented on European politics and society at the 2020 annual meeting of the American Political Science Association.

Award Committee: Jonathan Polk, Lund University; Daphne Halikiopoulou, University of Reading; Jeremy Ferwerda, Dartmouth College

Co-Recipients: Donghyun Danny Choi, University of Pittsburgh; Mathias Poertner, University of Texas A\&M; Nicholas Sambanis, University of Pennsylvania

Title: "The Hijab Penalty: Feminist Backlash to Muslim Immigrants." Presented at the 2020 APSA Annual Meeting.

Co-Recipient: Gemma Dipoppa, University of Pennsylvania Title: "How Criminal Organizations Expand to Strong States: Migrant Exploitation and Political Brokerage in Northern Italy." Presented at the 2020 APSA Annual Meeting.

\section{SECTION 22: STATE POLITICS AND POLICY}

\section{Career Achievement Award}

This annual award is given to a political scientist who has made a significant lifetime contribution to the study of politics and policy in the American states.

Award Committee: Anthony Nownes (Chair), University of Tennessee; Brent Boyea, University of Texas at Arlington; Patricia Kirkland, Princeton University

Recipient: Lynda W. Powell, University of Rochester
Virginia Gray Book Award

This annual award is given to the author(s) of the best political science book published on the subject of US state politics or policy in the preceding three calendar years.

Award Committee: Edward L. Lascher, Jr. (Chair), California State University, Sacramento; Patrick Flavin, Baylor University; Kathleen Marchetti, Dickinson College

Recipient: Leah C. Stokes, University of California, Santa Barbara Title: Short Circuiting Policy: Interest Groups and the Battle Over Clean Energy and Climate Policy in the American States. Oxford University Press, 2020.

\section{Christopher Z. Mooney Best Dissertation Prize}

This annual award is given to the author of the best $\mathrm{PhD}$ dissertation in American state politics and policy completed during the previous calendar year. The winner receives a plaque and $\$ 1000$. Support for this prize comes from the annual return of the endowed Mooney Fund.

Award Committee: Shauna Reilly (Chair), Northern Kentucky University; Erin Heidt-Forsythe, Pennsylvania State University; Benjamin Melusky, Old Dominion University

Recipient: Scott LaCombe, Smith College

Title: "Institutional Design and the Politics of US States."

State Politics and Policy Quarterly Best Paper Presented at a Professional Meeting

This annual award is given to the author(s) of the best paper on state politics and policy presented (or scheduled to have been presented) at any professional meeting in the previous calendar year.

Award Committee: Brianne Heidbreder (Chair), Kansas State University; James Avery, Stockton University; Gregory Shufeldt, Butler University

Recipients: Peter Bucchianeri, Vanderbilt University; Craig Volden, University of Virginia; Alan E. Wiseman, Vanderbilt University

Title: "Legislative Effectiveness in the American States."

Recipient: Zoe Nemerever, University of California, San Diego

Title: "Rural Representation in the American States."

Best Journal Article Award

This annual award is given to the author(s) of the best journal article on US state politics or policy published during the previous calendar year in any peer-reviewed journal (book reviews, review essays, and chapters published in edited volumes are not eligible).

Award Committee: William Franko (Chair), West Virginia University; Thomas J. Hayes, University of Connecticut; Abby Matthews, State University of New York at Buffalo

Recipients: Jeffrey J. Harden, University of Notre Dame and Justin H. Kirkland, University of Virginia

Title: "Does Transparency Inhibit Political Compromise?" American Journal of Political Science, Early View, September, 2020.

Recipient: Srinivas Parinandi, University of Colorado Title: "Policy Inventing and Borrowing among State Legislatures." American Journal of Political Science 64(4): 852-868. 2020.

\section{SECTION 23: POLITICAL COMMUNICATION}

Doris Graber Outstanding Book Award

The Doris Graber Outstanding Book Award is given to the most outstanding book in the field of political communication that was published in the past decade.

Award Committee: Abby Jones (Chair), AJ Research; Sharon Jarvis, University of Texas at Austin; Bob Boynton, University of lowa Recipients: Bethany Albertson, University of Texas at Austin and Shana Kushner Gadarian, Syracuse University 
Title: Anxious Politics: Democratic Citizenship in a Threatening World. Cambridge University Press, 2015.

\section{Paul Lazarsfeld Best Paper Award}

The Paul Lazarsfeld Award recognizes the best paper on political communication presented at the previous year's APSA annual meeting or Political Communication preconference.

Award Committee: Sean Richey (Chair), Georgia State University; Mel Atkinson, University of North Carolina, Charlotte; Alcides Velasquez, University of Kansas

Recipient: Sumitra Badrinathan, University of Pennsylvania and University of Oxford

Title: "Educative Interventions to Combat Misinformation: Evidence from a Field Experiment in India."

Timothy E. Cook Best Graduate Student Paper Award The Timothy E. Cook Award recognizes the best paper on political communication presented by a graduate student at the previous year's APSA Annual Meeting or Political Communication pre-conference. Preference will be given to papers presented in the Politica Communication Section.

Award Committee: David Weaver (Chair), Boise State University; Chrysi Dagoula, University of Groningen; Emily Sydnor, Southwestern University

Recipient: Erin Rossiter, Washington University

Title: "The Consequences of Interparty Conversation on Outparty Affect and Stereotypes."

\section{Thomas E. Patterson Best Dissertation Award}

The Thomas E. Patterson Best Dissertation Award recognizes the best dissertation completed in the field of political communication in the previous year.

Award Committee: Ashley Muddiman (Chair), University of Kansas; Jill Edy, University of Oklahoma; Juan Larrosa Fuentes, Instituto Tecnológico y de Estudios Superiores de Occidente Recipient: Yini Zhang, State University of New York at Buffalo Title: "A Network Approach to Understanding Public Attention, Public Opinion and Communication Flows In The Digital Media System." University of Wisconsin - Madison, 2020.

Honorable Mention: Sarah Shugars, New York University Title: "Reasoning Together: Network Methods for Political Talk and Normative Reasoning."

Honorable Mention: Alyt Damstra, University of Amsterdam Title: "Economic news. How it's made and how it matters."

\section{Walter Lippmann Best Published Article Award} The Walter Lippmann Best Published Article Award recognizes the best article published in the field of political communication in the previous calendar year.

Award Committee: Rosalee Clawson (Chair), Purdue University; Nuri Kim, Nanyang Technological University; Seth Goldman, University of Massachusetts Amherst

Recipients: Jason C. Coronel, Ohio State University; Shannon Poulsen, Ohio State University; Matthew D. Sweitzer, Ohio State University

Title: "Investigating the generation and spread of numerical misinformation: A combined eye movement monitoring and social transmission approach." Human Communication Research, 2020.

Honorable Mention: Andrew Guess, Princeton University; Michael Lerner, University of Michigan; Benjamin Lyons, University of Utah; Jacob Montgomery, Washington University in St. Louis; Brendan Nyhan, Dartmouth College; Jason Reifler, University of Exeter; Neelanjan Sircar, Ashoka University
Title: "A Digital Media Literacy Intervention Increases Discernment Between Mainstream and False News In The United States And India." PNAS, 117, 15536-15545.

Murray Edelman Lifetime Distinguished Career Award The Murray Edelman Distinguished Career Award recognizes a lifetime contribution to the study of Political Communication.

Award Committee: Sarah Oates (Chair), University of Maryland; Josh Pasek, University of Michigan; Eunii Kim, Vanderbilt University

Recipient: Pippa Norris, Harvard University

\section{SECTION 24: POLITICS AND HISTORY}

\section{J. David Greenstone Book Prize}

The J. David Greenstone Book Prize recognizes the best book in history and politics in the past two calendar years.

Award Committee: Chris Howard, The College of William \& Mary; Chloe Thurston, Northwestern University; James Mahoney, Northwestern University

Co-Recipient: Henrik Spruyt, Northwestern University Title: The World Imagined: Collective Beliefs and Political Order in the Sinocentric, Islamic and Southeast Asian International Societies. Cambridge University Press, 2020.

Co-Recipients: Boris Heersink, Fordham University and Jeff Jenkins, University of Southern California

Title: Republican Party Politics and the American South, 1865 -

1968. Cambridge University Press, 2020.

\section{Mary Parker Follett Prize}

The Mary Parker Follett Prize recognizes the best article on Politics and History published in the previous year.

Award Committee: Alexandra Cirone, Cornell University; Daniel Galvin, Northwestern University; Kathleen Sullivan, Ohio University

Recipient: Agustina S. Paglayan, University of California, San Diego

Title: "The Non-Democratic Roots of Mass Education: Evidence from 200 Years." American Political Science Review, 115(1), February 2021,179 - 198.

\section{Walfer Dean Burnham Dissertation Award}

The Walter Dean Burnham Award is given for the best dissertation in the field of Politics and History.

Award Committee: Matthew Berkman, Oberlin College; Lee Ann Banaszak, Pennsylvania State University; Alexis Walker, St. Martin's University

Recipient: Brendan McElroy, University of Michigan

Title: "Peasants and Parliaments: Agrarian Reform in Eighteenth Century Europe."

\section{Best Paper Award}

An award for the best paper in Politics and History presented at the previous annual meeting.

Award Committee: Andrea Louise Campbell, Massachusetts Institute of Technology, Isabela Mares, Yale University, Daniel Schlozman, Johns Hopkins University

Recipient: Matthew Denney, Yale University Title: "To Wage a War': Crime, Race, and State-Making in the Age of FDR."

\section{SECTION 25: POLITICAL ECONOMY}

McGillivray Best Paper Award

The McGillivray Best Paper Award is given for the best paper in 
Political Economy presented at the previous year's APSA Annual Meeting.

Award Committee: In Song Kim (Chair), Massachusetts Institute of Technology; Rabia Malik, University of Essex; Fiona Shen-Bayh, The College of William and Mary

Recipients: Nikhar Gaikwad, Columbia University; Erin Lin, Ohio State University; Noah Zucker, Columbia University

Title: "Genocide and the Gender Gap in Political Representation."

\section{Michael Wallerstein Award}

The Michael Wallerstein Award is given for the best published article in Political Economy in the previous calendar year.

Award Committee: Nita Rudra (Chair), Georgetown University; Saumitra Jha, Stanford University; Elias Dinas, University of Oxford/ EUI

Recipient: Agustina S. Paglayan, University of California, San Diego

Title: "The non-democratic roots of mass education: evidence from 200 years." American Political Science Review 115 (1): 179-98.

Honorable Mention: Francesc Amat, Universitat de Barcelona and Pablo Beramendi, Duke University

Title: "Democracy under High Inequality: Capacity, Spending, and Participation." The Journal of Politics 82 (3): 859-78.

\section{Mancur Olson Best Dissertation Award}

The Best Dissertation Award, named for Mancur Olson, is given for the best dissertation in political economy completed in the previous two years.

Award Committee: Jan Pierskalla (Chair), Ohio State University; Robin Harding, Oxford University; Guadalupe Tuñon, Princeton University

Recipient: Jorge Mangonnet, Columbia University

Tiłle: "Property Formation, Labor Repression, and State Capacity in Imperial Brazil." Columbia University, 2020.

Honorable Mention: Tugba Bozcaga, Massachusetts Institute of Technology

Title: "Essays on the Political Economy of Service Provision." Massachusetts Institute of Technology, 2020.

\section{William H. Riker Book Award}

The Best Book Award, named for William H. Riker, is given for the best book on political economy published during the past three calendar years.

Award Committee: Frances Rosenbluth (Chair), Yale University; Avi Acharya, Stanford University; Lauren Young, University of California, Davis

Recipient: Anne Meng, University of Virginia

Title: Constraining Dictatorship: From Personalized Rule to Institutionalized Regimes. Cambridge University Press, 2020.

Honorable Mention: Guillermo Trejo, University of Notre Dame and Sandra Ley, Centro de Investigación y Docencia Económicas Title: Votes, Drugs and Violence: The Political Logic of Criminal Wars in Mexico. Cambridge University Press, 2020.

\section{SECTION 27: NEW POLITICAL SCIENCE}

\section{Christian Bay Award}

The Christian Bay Award recognizes the best paper presented on a new political science panel at the previous year's annual meeting.

Award Committee: Gregory Koutnik (Chair), University of Pennsylvania; Lucrecia Garcia-lommi, Fairfield University; John Berg, Suffolk University (Emeritus)

Recipient: Joanna Wuest, Princeton University

Title: "The Impossibility of Liberation: Queer Political Thought Since the New Left?"

Richard Cloward and Frances Fox Piven Award The Richard Cloward and Frances Fox Piven Award recognizes an activist group, in the region of the annual meeting, that puts the ideals of the New Political Science Section, "to make the study of politics relevant to the struggle for a better world," into practice.

Award Committee: Michael Forman (Chair), University of Washington; Kevin Funk, Trinity College; Edwin Daniel Jacob, Arizona State University; Frances Fox Piven (Honorary), The Graduate Center, City University of New York (Emeritus)

Recipient: Familias Unidas por la Justicia, Burlington, Washington

Charles A. McCoy Career Achievement Award

The Charles A. McCoy Career Achievement Award recognizes a progressive political scientist who has had a long, successful career as a writer, teacher, and activist.

Award Committee: Rosalind Petchesky (Chair), Hunter College, City University of New York; Laura Katz Olson, Lehigh University; Terrell Carver, Bristol University; F. Peter Wagner, University of Wisconsin-Whitewater

Recipient: Cornel West, Union Theological Seminary

\section{Michael Harrington Book Award}

The Michael Harrington Book Award recognizes an outstanding book that demonstrates how scholarship can be used in the struggle for a better world.

Award Committee: Joseph Peschek (Chair), Hamline University; James Simmons, University of Wisconsin - Oshkosh; Andrew Scerri, Virginia Tech University; Matthew Evans, Northwest Arkansas Community College; Rebecca Tarlau (Honorary), Pennsylvania State University

Recipient: Albena Azmanova, University of Kent, Brussels School of International Studies

Title: Capitalism on Edge: How Fighting Precarity Can Achieve Radical Change Without Crisis or Utopia. Columbia University Press, 2020.

Stephen Eric Bronner Dissertation Award For an outstanding Political Science dissertation finished within the previous year of the APSA Meeting which exemplifies the commitment to use scholarship in the struggle for a better world.

Award Committee: Lucas Pinheiro (Chair), University of Chicago; William Sokoloff, University of Texas Rio Grande Valley; Mindy Peden, John Carroll University; Stephen Eric Bronner (Honorary), Rutgers University (Emeritus)

Recipient: Matt York, University College, Cork, Ireland Title: "Imagining New Worlds: (R)evolutionary Love and Radical Social Transformation in the 21 st Century."

\section{SECTION 28: POLITICAL PSYCHOLOGY}

Robert E. Lane Book Award

The Robert E. Lane Award for the best book in political psychology published in the past year.

Award Committee: Ashley Jardina, Duke University; Alex Theodoridis, University of Massachusetts Amherst; Cindy Kam, Vanderbilt University

Recipient: Nichole M. Baver, Louisiana State University

Title: The Qualifications Gap: Why Women Must Be Better than

Men to Win Political Office. Cambridge University Press.

Best Dissertation Award

The Best Dissertation Award is given for the best dissertation in politi- 
cal psychology filed during the previous year.

Award Committee: Hakeem Jefferson, Stanford University; Eunji Kim, Vanderbilt University; Jennifer Merolla, University of California, Riverside

Recipient: Matt Nelsen, University of Chicago

Title: "Educating for Empowerment: Race, Socialization, and Reimagining Civic Education." Northwestern University.

\section{Best Paper Award}

The Best Paper Award is given to the most outstanding paper in political psychology delivered at the previous year's Annual Meeting.

Award Committee: Steven Moore, Wesleyan University; Steven Webster, Indiana University; Allison Anoll, Vanderbilt University

Recipient: Elizabeth Connors, University of South Carolina

Title: "Social Context Shapes Affective Polarization." Unpublished manuscript presented at the APSA Annual Meeting, 2020.

\section{Distinguished Junior Scholar Award}

The APSA Political Psychology section gives Distinguished Junior Scholar Awards as grants to junior scholars (graduate students or those no more than seven years since receiving their $\mathrm{PhD}$ ) to help fund their travel to the APSA meeting.

Award Committee: Brian F. Harrison, University of Minnesota; Christopher Federico, University of Minnesota; Samara Klar, University of Arizona

Recipients: Chryl Laird, Bowdoin College and Nic Dias, University of Pennsylvania

Hazel Gaudet Erskine Career Achievement Award This award recognizes a scholar whose lifetime scholarship and service to the profession has made an outstanding contribution to the field of political psychology.

Award Committee: Lynn Vavreck, University of California, Los Angeles; Michael Tesler, University of California, Irvine; Cecilia Mo, University of California, Berkeley

Recipient: Shanto lyengar, Stanford University

\section{SECTION 29: POLITICAL SCIENCE EDUCATION}

The Craig L. Brians Award for Excellence in Undergraduate Research and Mentorship

Established in 2014 in memory of Dr. Craig L. Brians, this award is given annually to a faculty member who demonstrates commitment to and excellence in encouraging and developing scholarship among undergraduate students, and in mentoring undergraduate students in preparation for graduate school or public-affairs related careers.

Award Committee: J. Cherie Strachan, Central Michigan University and Megan Becker, University of Southern California

Recipient: Judithanne McLauchlan, University of South Florida

\section{The Best APSA Conference Paper Award}

This award is given annually at the section meeting held in conjunction with the APSA annual meeting to the author(s) who present at the previous year's annual APSA annual meeting, either in an oral session or poster session.

Award Committee: Maureen Feeley, University of California, San Diego and Matthew Platt, Morehouse College

Recipients: Christopher L. Brown, Georgia State University; Jeannie Grussendorf, Georgia State University; Michael Shea, Georgia State University; Clark DeMas, Georgia State University

Title: "Changing the Paradigm? Creating an Adaptive Course to Improve Student Engagement and Outcomes in Introductory Political Science Classes."
The Lifetime Achievement Award

This award may be given at the annual section meeting held at the APSA annual meeting. The awardee must have a strong record of long-standing, exceptional, and extensive contributions to the goals of the section, including the promotion of the teaching and learning in the discipline and the scholarship of teaching.

Award Committee: Terry Gilmour, Midland College; Megan Becker, University of Southern California; Rachel Bzostsek Walker, Collin College; Maureen Feeley, University of California, San Diego; Mark Carl Rom, Georgetown University; J. Cherie Strahan, Central Michigan University; Patrick McKinlay, Morningside College

Recipient: Michelle Deardorff, University of Tennessee at Chattanooga

\section{The Distinguished Service Award}

This award may be given at the section meeting held at the APSA meeting. The awardee has a strong record of exceptional and extensive contributions to the goals of the section, including the promotion of teaching and learning in the discipline and the scholarship of teaching.

Award Committee: Terry Gilmour, Midland College; Megan Becker, University of Southern California; Rachel Bzostsek Walker, Collin College; Maureen Feeley, University of California, San Diego; Mark Carl Rom, Georgetown University; J. Cherie Strahan, Central Michigan University; Patrick McKinlay, Morningside College

Recipient: Juan Carlos Huerta, Texas A\&M University - Corpus Christi

\section{SECTION 30: POLITICS, LITERATURE, AND FILM}

Wilson Carey McWilliams Award

The Wilson Carey McWilliams Award for Best Paper in Politics, Literature and Film.

Award Committee: Rob Watkins, Columbia College Chicago; Katie Robiadek, Hood College; Eunji Kim, Vanderbilt University

Recipient: Elizabeth Barringer, Bard College

Title: "Skulls and Flags: Contemporary Appropriations of Marvel's Punisher"

\section{Pamela Jensen Award}

The Dr. Pamela Grande Jensen Award for Best Book in Politics, Literature and Film.

Award Committee: Lori Marso, Union College; James Martel, San Francisco State University; Judith Grant, Ohio State University Recipient: Michael J. Shapiro, University of Hawai'i at Manoa Title: Punctuations: How the Arts Think the Political. Duke University Press, 2019.

\section{SECTION 31: FOREIGN POLICY}

\section{Best Paper Award}

Recognizing an outstanding paper submitted at the 2020 APSA Annual Convention that was submitted to and presented on a Foreign Policy Section Panel.

Award Committee: Danielle Lupton, Colgate University; Brent Sasley, University of Texas at Arlington; Anthony Lopez, Washington State University

Recipients: Kathleen Powers, Dartmouth College and Dan Altman, Georgia State University

Title: "The Puzzle of Coercion Failure: How Psychology Explains Resistance to Threats." Presented at the 2020 APSA Annual Meeting. 


\section{Best Graduate Student Paper Award}

Recognizing an outstanding paper, written by a graduate student, submitted at the 2020 APSA Annual Convention that was submitted to and presented on a Foreign Policy Section Panel.

Award Committee: Jacqueline Hazelton, Naval War College; Nola Hayes, University of Southern California; Dov Levin, The University of Hong Kong

Recipient: Rachel Myrick, Stanford University

Title: "Do External Threats Unite or Divide?" Presented at the 2019 APSA Annual Meeting.

Honorable Mention: Naima Green-Riley, Harvard University Title: "How Perilous are Paper Fans? Public Diplomacy through Confucius Classrooms and Implications for Chinese Influence." Presented at the 2020 APSA Annual Meeting.

\section{Best Book Award}

Research-based book published by a scholarly press during the preceding two years.

Award Committee: Christine Sixta Rinehart, University of South Carolina; A. Burcu Bayram, University of Arkansas; Thomas M. Dolan, University of Central Florida

Recipient: Brian Rathbun, University of Southern California Title: Reasoning of State: Realists, Romantics, and Rationality in International Relations. Cambridge University Press, 2019.

Honorable Mention: Danielle Lupton, Colgate University Title: Reputation for Resolve: How Leaders Signal Determination in International Politics. Cornell University Press, 2020.

Honorable Mention: Sebastian Schmidt, Johns Hopkins University

Title: Armed Guests: Territorial Sovereignty and Foreign Military Basing. Oxford University Press, 2020.

\section{SECTION 32: ELECTIONS, PUBLIC OPINION, AND VOTING BEHAVIOR}

Philip E. Converse Book Award For an outstanding book in the field published at least 5 years before.

Award Committee: Christopher Karpowitz. Bingham Young University; Tim Ryan, University of North Carolina at Chapel Hill; Susan Banducci, University of Exeter

Recipients: Samara Klar, University of Arizona and Yanna Krupnikov, SUNY Stony Brook University

Title: Independent Politics: How American Disdain for Parties Leads to Political Inaction. Cambridge University Press, 2016.

\section{Emerging Scholars Award}

Recognizing a top scholar in the field who is within 10 years of the PhD.

Award Committee: Eva Anduiza (Chair), Universitat Autònoma de Barcelona; Brendan Nyhan, Dartmouth College; Peter Loewen, University of Toronto

Recipients: Noam Lupu, Vanderbilt University and Lauren Davenport, Stanford University

\section{Best Paper Award}

Recognizing an EPOVB paper delivered at APSA 2020.

Award Committee: Yanna Krupnikov (Chair), State University of New York at Stony Brook; Ruth Dassonneville, University of Montreal; Airo Hino, Waseda University

Recipient: Mathias Poertner, Texas A\&M University

Title: "Does Political Representation Increase Participation? Evidence from Party Candidate Lotteries in Mexico."
Best Article in Political Behavior

Recognizing the best article published during 2020 in the EPOVB section journal Political Behavior.

Award Committee: Barry Burden (Chair), University of Wisconsin - Madison; Cecilia Mo, University of California, Berkeley; Samara Klar, University of Arizona

Co-Recipients: Rachel Bernhard. University of California, Davis and Sean Freeder, University of California, Berkeley

Title: "The More You Know: Voter Heuristics and the Information Search." Political Behavior, 42: 603-623, 2020.

Co-Recipients: Nicole Yadon, Ohio State University and Mara C. Ostfeld, University of Michigan

Title: "Shades of Privilege: The Relationship between Skin Color and Political Attitudes Among White Americans." Political Behavior, 42, 2020.

John Sullivan Award

Recognizing a paper delivered by a graduate student on an APSA 2020 EPOVB panel.

Award Committee: Michael Tesler (Chair), University of California, Irvine; Elizabeth C. Connors, University of South Carolina; Liliana Mason, University of Maryland

Recipient: Mike Cowburn, Freie Universität Berlin

Title: "Ideological Difference \& Party Destabilization in Congressional Primary Contests."

\section{SECTION 33: RACE, ETHNICITY AND POLITICS}

\section{Best Book Award}

The REP Section's annual book awards recognize the very best research exploring the multiple junctures between politics and issues of race, ethnicity, immigration, and indigeneity, as well as their intersections with other axes of identity and marginalization.

Award Committee: Matt Barreto, University of California, Los Angeles; Rene Rocha, University of lowa; Karam Dana, University of Washington Bothell

Co-Recipients: Ismail White, Princeton University and Chryl Laird, University of Maryland

Tiłle: Steadfast Democrats: How Social Forces Shape Black Political Behavior. Princeton University Press, 2020.

Co-Recipients: Mark D. Ramirez, Arizona State University and David A. M. Peterson, lowa State University

Title: Ignored Racism: White Animus Toward Latinos. Cambridge University Press, 2020.

\section{Best Paper Award}

The Best Paper Award is given for the best paper on Race, Ethnicity, and Politics presented at the previous year's APSA Annual Meeting.

Award Committee: Hannah Walker, University of Texas at Austin; Yamil Velez, Columbia University; John Kuk, University of Oklahoma

Co-Recipients: Nicole Yadon, Ohio State University and Mara Ostfeld, University of Michigan

Title: "¿Mejorando La Raza?: The Political Undertones Of Latinos' Skin Color In The US"

Co-Recipients: Chinbo Chong, Indiana University and Tanika Raychaudhuri, Princeton University

Title: "Group-based belief systems about the racial order: Racial stereotypes and Asian American partisan identification."

\section{SECTION 34: INTERNATIONAL HISTORY AND POLITICS} Robert L. Jervis and Paul W. Schroeder Best Book Award

This award is for the best book on International History and Politics. 
The award may be granted to a single-authored or multi-authored book, or to an edited volume, and will be given to works published in the calendar year prior to the year of the APSA meeting at which the award is presented.

Award Committee: Etel Solingen, University of California, Irvine; Jelena Subotic, Georgia State University; Ahmet Kuru, San Diego State University

Recipient: Kyle Lascurettes, Lewis and Clark College

Title: Orders of Exclusion: Great Powers and the Strategic Sources of Foundational Rules in International Relations. Oxford University Press.

Recipient: Dov Levin, University of Hong Kong

Title: Meddling at the Ballot Box: The Causes and Effects of Partisan Electoral Interventions. Oxford University Press.

Honorable Mention: Lora Viola, Freie Universität Berlin Title: The Closure of the International System. Cambridge University Press.

Outstanding Article Award in International History and Politics

The Outstanding Article Award in International History and Politics recognizes exceptional peer-reviewed journal articles representing the mission of the International History and Politics Section of the American Political Science Association, including innovative work that brings new light to events and processes in international politics, encourages interdisciplinary conversations between political scientists and historians, and advances historiographical methods. The Outstanding Article Award is given to a published article that appeared in print in the calendar year preceding the APSA meeting at which the award is presented (2020).

Award Committee: Timothy Crawford (Chair), Boston College; Sarah Parkinson, Johns Hopkins University; Eric Hundman, New York University, Shanghai

Recipient: Yasuhiro Izumikawa, Chuo University

Title: "Network Connections and the Emergence of the Hub-andSpokes Alliance System in East Asia." International Security, 45 (2): 7-50.

\section{SECTION 35: DEMOCRACY AND AUTOCRACY}

\section{Best Article Award}

Single-authored or co-authored articles focusing on democratization and/or the development and dynamics of democracy and authoritarianism, published in print in 2020 are eligible.

Award Committee: Tarek Masoud (Chair), Harvard University; Amanda Edgell, University of Alabama; Aditya Dasgupta, University of California, Merced

Co-Recipients: Vilde Lunnan Djuve, University of Oslo; Carl Henrik Knutsen, University of Oslo; Tore Wig, University of Oslo

Title: "Patterns of Regime Breakdown Since the French Revolution," Comparative Political Studies, 2020.

Co-Recipients: Matthew Graham, George Washington University and Milan Svolik, Yale University

Title: "Democracy in America? Partisanship, Polarization, and the Robustness of Support for Democracy in the United States." American Political Science Review, 2020.

Honorable Mention: Sharan Grewal, College of William and Mary

Tiłle: "From Islamists to Muslim Democrats: The Case of Tunisia's Ennahda." American Political Science Review, 2020.

Honorable Mention: Robin Harding, University of Oxford Title: "Who Is Democracy Good For? Elections, Rural Bias, and Health and Education Outcomes in Sub-Saharan Africa." Journal of Politics, 2020.

\section{Best Book Award}

Given for the best book focusing on democratization and/or the development and dynamics of democracy and authoritarianism, published in print in 2020.

Award Committee: Irfan Nooruddin (Chair), Georgetown University; Mariela Daby, Reed College; Danny Choi, University of Pittsburgh

Co-Recipients: Guillermo Trejo, University of Notre Dame and Sandra Ley, Centro de Investigación y Docencia Económicas, Mexico

Title: Votes, Drugs, and Violence.

Co-Recipient: Daniel Mattingly, Yale University

Title: The Art of Political Control.

Best Fieldwork Award

This prize rewards dissertation students who conduct innovative and difficult fieldwork on the topics of democratization and/or the development and dynamics of democracy and authoritarianism.

Award Committee: Kurt Weyland (Chair), University of Texas at Austin; Natalie Letsa, University of Oklahoma; Basak Taraktas, Boğaziçi University

Recipient: Mashail Malik, Harvard University

Title: "The Microfoundations of Identity Politics in Pakistan's Megacity."

Honorable Mention: Michelle Weitzel, University of Basel

Title: "Drones, Sirens, and Prayer Calls: Unheard Consequences of a Politics of Sound."

\section{Best Paper Award}

Given to the best paper on democratization and/or the development and dynamics of democracy and authoritarianism presented at the 2020 APSA Convention.

Award Committee: Adrienne LeBas (Chair), American University; Matt Winters, University of Illinois; Howard Sanborn, Virginia Military Institute

Recipients: Nikhar Gaikwad, Columbia University; Erin Lin, Ohio State University; Noah Zucker, Columbia University

Title: "Genocide and the Gender Gap in Political Representation."

Juan Linz Best Dissertation Award

Given for the best dissertation on democratization and/or the development and dynamics of democracy and authoritarianism completed and accepted in the two calendar years immediately prior to the 2021 APSA Annual Meeting (i.e., 2019 or 2020).

Award Committee: Ozge Kemahlioglu (Chair), Sabancı University; Francisco Garfias, University of California, San Diego; Carl LeVan, American University

Recipient: Christopher Carter, University of California, Berkeley Title: "States of Extraction: The Emergence and Effects of Indigenous Autonomy in the Americas."

Honorable Mention: Jane Esberg, Princeton University Title: "Strategies of Repression in Pinochet's Chile."

\section{SECTION 36: HUMAN RIGHTS}

\section{Best Dissertation Award}

Dissertation making the greatest contribution to the field of human rights in the previous calendar year. Please send a copy to each member of the committee.

Award Committee: Marijke Breuning, University of North Texas; Lucas Swaine, Dartmouth College; Brian Greenhill, State University of New York at Albany,

Recipient: Anthony DeMattee, Indiana University

Title: "Domesticating Civil Society: How and Why Governments Use Laws to Regulate CSOs." Indiana University, 2020. 


\section{Best Book Award}

This competition is open to all books on human rights written by a political scientist and published in the previous calendar year.

Award Committee: George Andreopoulos (chair), City University of New York; Alison Dundes Renteln, University of Southern California; Lucrecia García lommi, Fairfield University

Recipients: Adam Chilton, University of Chicago and Mila Versteeg, University of Virginia

Title: How Constitutional Rights Matter. Oxford University Press, 2020.

\section{Best Paper Award}

This award recognizes the best paper presented on a Human Rights Section Panel at the APSA Annual Meeting.

Award Committee: Brian Greenhill, State University of New York at Albany; Karen Zivi, Grand Valley State University; Shareen Hertel, University of Connecticut

Recipients: Xinyuan Dai, University of Illinois at Urbana-Champaign and Alexandros Tokhi, WBZ Berlin Social Science Center Title: "New Democracies, Sovereignty Costs, and Commitment to Human Rights Treaties." Unpublished manuscript presented at the APSA Annual Meeting, 2020.

\section{SECTION 38: SEXUALITY AND POLITICS}

Cynthia Weber Best Conference Paper Award The Best Conference Paper Award recognizes the best paper exploring sexuality and politics presented at the previous year's APSA Annual Meeting

Award Committee: Edward Kammerer, Idaho State University; Scott Nicholas Siegel, San Francisco State University; Anne Louise Schotel, University of Amsterdam

Recipient: Shih-chan Dai, University of Massachusetts Amherst Title: "Describing Sexual Minority and Gay Rights: A Longitudinal Analysis of Pro-and Anti-Gay Rights Groups' Online Messages in Taiwan."

\section{Kenneth Sherrill Best Dissertation Award}

The Best Dissertation Award recognizes the best dissertation on sexuality and politics completed and successfully defended in the previous two calendar years. The award is open to all scholarship that falls under the broad rubric of sexuality and politics, including studies concerning the regulation of sexuality, political responses to the regulation of sexuality, the uses of sexuality as a political construct, the intersections of sexuality with gender, race, and class, or LGBT politics and mobilizations.

Award Committee: Mellissa Michelson, Menlo College; Katherine McCabe, Rutgers University; Camilla Reutersward, University of Sussex

Recipient: Andrew Proctor, University of Minnesota Title: "Coming out to Vote: LGBT Mobilization in the Two-Party System, 1986-2016." PhD Princeton University

\section{Graduate Student Award}

Nominated by membership.

Recipient: Isabel Felix Gonzales, University of California, Riverside

\section{SECTION 39: HEALTH POLITICS AND POLICY}

Leonard S. Robins Award for the Best Paper on Health Politics and Policy

The section's Best Paper on Health Politics and Policy Award is named in honor of Leonard S. Robins, who through his presence and gentle questioning at virtually every health politics panel graciously nurtured the scholarship of both junior and senior scholars.
The award recognizes the best paper on any subject that fits under the rubric of Health Politics and Policy presented at the previous annual APSA meeting.

Award Committee: Sue Tolleson-Rinehart, University of North Carolina at Chapel Hill; Andrew Kelly, California State University, East Bay; Edward Miller, University of Massachusetts Boston; Juliana Pacheco, University of lowa

Recipients: Kristin Lunz Trujillo, University of Minnesota and Matthew Motta, Oklahoma State University

Title: "How Internet Access Drives Global Vaccine Skepticism." International Journal of Public Opinion Research.

Outstanding Public Engagement in Health Policy Award The Outstanding Public Engagement in Health Policy Award is offered to an individual who has contributed to health and health care system improvement through sustained engagement in the political and policy making process.

Award Committee: Sarah Gollust (Chair), University of Minnesota; Susan Moffitt, Brown University; Harold Pollack, University of Chicago; Matt Kavanagh, Georgetown University; Deborah Stone, Brandeis University

Recipient: Timothy S. Jost, Washington and Lee University

\section{SECTION 40: CANADIAN POLITICS}

Mildred Schwartz Lifetime Achievement in the Study of Canadian Politics

The Mildred A. Schwartz Lifetime Achievement Award goes to scholars who have made significant contributions through their career to the study of Canadian politics, either through development of political analysis of Canada or through incorporating Canada as a significant case in comparative political analyses.

Award Committee: Matthew Lebo, University of Western Ontario and Antoine Yoshinaka, State University of New York at Buffalo Recipient: Elisabeth Gidengil, McGill University

\section{SECTION 41 : POLITICAL NETWORKS}

The Political Ties Award

Awarded to the best article published on political networks in the past year.

Award Committee: Marina Duque (Chair), Florida State University; Cantay Caliskan, Denison University; Justin Kirkland, University of Virginia

Recipients: Adam Michael Auerbach, American University and Tariq Thachil, University of Pennsylvania

Title: "Cultivating Clients: Reputation, Responsiveness, and Ethnic Indifference in India's Slums." American Journal of Political Science, 64 (3): $471-87$.

\section{Best Book Award}

Awarded to the best article published on political networks in the past year.

Award Committee: Michael Kenney (Chair), University of Pittsburgh; Yunkyu Sohn, Waseda University; Sandra Gonzalez Bailon, University of Pennsylvania

Recipients: Andy Baker, University of Colorado, Boulder; Barry Ames, University of Pittsburgh; Lucio Renno, University of Brasília Title: Persuasive Peers: Social Communication and Voting in Latin America. Princeton University Press 2020.

\section{Best Conference Paper Award}

This award is given annually to the best paper on political networks presented by a faculty person delivered at a political science conference in the previous year. 
Award Committee: Debra Leiter (Chair), University of Missouri, Kansas City; Melina Platas, New York University; Hyunjin (Jin) Song, Yonsei University

Recipients: Ted Hsuan Yun Chen, Aalto University and University of Helsinki; Ali Salloum, Aalto University; Antti Gronow, University of Helsinki; Tuomas Yl 'a-Anttila, University of Helsinki; Mikko Kivelä, Aalto University

Title: "Polarization of Climate Politics Results from Partisan Sorting: Evidence from Finnish Twittersphere."

\section{John Sprague Award}

Awarded to the best paper on political networks presented by a graduate student at a conference in the past year.

Award Committee: Taylor Carlson (Chair), Washington University in St. Louis; Sarah Shugars, New York University; Sahar Abi-Hassan, Mills College

Recipient: Taegyoon Kim, Pennsylvania State University

Title: "Violent Political Rhetoric on Twitter."

\section{Career Achievement Award}

Award Committee: Betsy Sinclair (Chair), Washington University in St. Louis; Cesi Cruz, University of British Columbia and University of California, Los Angeles; Guy Grossman, University of Pennsylvania

Recipient: Scott McClurg, Southern Illinois University

\section{SECTION 42: EXPERIMENTAL RESEARCH}

\section{Best Dissertation Award}

The Best Dissertation Award recognizes the best dissertation completed in the previous calendar year that utilizes experimental methods on substantive questions about politics or makes a fundamental contribution to experimental methods.

Award Committee: Brendan Nyhan (Chair), Dartmouth College; Tesalia Rizzo, University of California, Merced; Darin Christensen, University of California, Los Angeles

Recipient: Tara Slough, New York University

Title: "Essays on the Distributive Politics of Bureaucracy."

\section{Best Paper Award}

The Best Paper Award recognizes a paper that was scheduled to be presented at APSA in the previous year and features experimental research.

Award Committee: Alex Theodoridis (Chair), University of Massachusetts Amherst; Lucy Martin, University of North Carolina at Chapel Hill; Salma Mousa, Stanford University and Yale University

Recipients: Robert A. Blair, Brown University; Manuel Moscoso, Brown University; Andres Vargas Castillo, Yale University; Michael Weintraub, Universidad de los Andes

Title: "After Rebel Governance: A Field Experiment in Security and Justice Provision in Rural Colombia."

Honorable Mention: Mathias Poertner, Texas A\&M University and London School of Economics and Political Science

Title: "Does Political Representation Increase Participation? Evidence from Party Candidate Lotteries in Mexico."

\section{Best Book Award}

The Best Book Award recognizes the best book published in 2020 that either uses or is about experimental research methods in the study of politics.

Award Committee: Evan Lieberman (Chair), Massachusetts Institute of Technology; Samara Klar, University of Arizona; Gareth Nellis, University of California, San Diego
Recipient: Ana Bracic, Michigan State University

Title: Breaking the Exclusion Cycle: How to Promote Cooperation between Majority and Minority Ethnic Groups. Oxford University Press, 2020.

\section{Public Service Award}

Many experiments only occur thanks to the assistance of non-researchers who provide access to resources and data. This award recognizes a special form of public service, the facilitation of randomized experiments in political science by those outside the academy.

Award Committee: Dan Hopkins (Chair), University of Pennsylvania; Page Gardner, Women's Voices Women Vote Action Fund (WVWVAF) and Voter Participation Center (VPC); Guy Grossman, University of Pennsylvania

Recipient: David Yokum, The Policy Lab, Brown University

\section{Rebecca Morton Award for Best JEPS Article}

This award is for the best research article published in the previous year in the Journal of Experimental Political Science.

Award Committee: Kevin Arceneaux, Sciences Po, Paris; Bert Bakker, University of Amsterdam; Cheryl Boudreau, University of California, Davis

Recipients: Florian Foos, London School of Economics and Fabrizio Dilardi, University of Zurich

Title: "Does Exposure to Gender Role Models Increase Women's Political Ambition? A Field Experiment with Politicians." Journal of Experimental Political Science, 7 (3): 157-66.

Best Article with a Preregistration in JEPS Award Award Committee: Kevin Arceneaux, Sciences Po, Paris; Bert Bakker, University of Amsterdam; Cheryl Boudreau, University of California, Davis

Recipients: Daniel J. Hopkins, University of Pennsylvania; Cheryl R. Kaiser, University of Washington; Efrén O. Pérez, University of California, Los Angeles; Sara Hagá, Universidade de Lisboa; Corin Ramos, University of Texas at El Paso; Michael Zárate, University of Texas at El Paso

Title: "Does Perceiving Discrimination Influence Partisanship among US Immigrant Minorities? Evidence from Five Experiments." Journal of Experimental Political Science, 7 (2): 112-36.

\section{Best Replication in JEPS Award}

Award Committee: Kevin Arceneaux, Sciences Po, Paris; Bert Bakker, University of Amsterdam; Cheryl Boudreau, University of California, Davis

Recipients: Costas Panagopoulos, Northeastern University and Kendall Bailey, Northeastern University

Title: "'Friends-and-Neighbors' Mobilization: A Field Experimental Replication and Extension." Journal of Experimental Political Science, 7 (1), 13-26.

\section{SECTION 43: MIGRATION AND CITIZENSHIP}

\section{Best Book Award}

Award for best book on migration and/or citizenship published in the previous year (i.e., copyright and printed in 2020).

Award Committee: Ines Valdez (Chair), Ohio State University; Janice Fine, Rutgers University-New Brunswick; Loren Landau, University of Oxford

Co-Recipients: Allan Colbern, Arizona State University and S. Karthick Ramakrishnan, University of California, Riverside Title: Citizenship Re-Imagined. A New Framework for State Rights in the United States. New York: Cambridge University Press. 
Co-Recipient: Lauren Duquette-Rury, Wayne State University Title: Exit and Voice. The Paradox of Cross-Border Politics in Mexico. Berkeley: University of California Press.

\section{Best Article Award}

Award for best article on migration and/or citizenship published (i.e., printed) in the previous calendar year.

Award Committee: Kimberly Morgan (Chair), George Washington University; Guy Grossman, University of Pennsylvania; Agustin Goenaga, Lund University

Co-Recipients: Aala Abdelgadir, Stanford University and Vasiliki Fouka, Stanford University

Title: "Political Secularism and Muslim Integration in the West: Assessing the Effects of the French Headscarf Ban." American Political Science Review, 114 (3):707-23.

Co-Recipients: Rafaela M. Dancygier, Princeton University and Yotam Margalit, Tel Aviv University

Title: "The Evolution of the Immigration Debate: Evidence from a New Dataset of Party Positions Over the Last Half-Century." Comparative Political Studies, 53 (5): 734-74.

\section{Best Dissertation Award}

Award for best dissertation on migration and/or citizenship accepted in the previous calendar year.

Award Committee: Lina Newton (Chair), Hunter College, CUNY; Colin M. Brown, Northeastern University; Beth Elise Whitaker, University of North Carolina at Charlotte

Recipient: Elif Naz Kayran, Institut De Hautes Études Internationales et Du Developpement

Title: "Political Responses and Electoral Behaviour at Times of Socioeconomic Risk Inequalities and Immigration."

\section{Best Graduale Paper}

Award for best paper on migration and/or citizenship presented by a graduate student at the 2020 APSA Annual Meeting (either as part of a panel or poster session).

Award Committee: Christine Brenner (Chair), University of Massachusetts Boston; Barbara Buckinx, Princeton University; James Hollifield, Southern Methodist University

Recipient: Aala Abdelgadir, Stanford University

Title: "The Dynamics of Refugee Return: Syrian Refugees and Their Migration Intentions."

\section{SECTION 45: CLASS AND INEQUALITY}

\section{Best Paper Award}

For the best paper presented at a panel sponsored by (or co-sponsored by) the Class and Inequality Section at the 2020 virtual APSA Annual Meeting.

Award Committee: Kris-Stella Trump (Chair), University of Memphis; Christopher Ojeda, University of California, Merced; Patricia Posey, University of Chicago

Recipients: Lucia Motolinia, New York University; Marko Klašnja, Georgetown University; Simon Weschle, Syracuse University Title: "The Political Selection Effects of Campaign Finance Rules." Unpublished manuscript presented at the APSA Annual Meeting, 2020.

Best Paper on Economic and Social Inequality For best paper among those presented on any panel at the 2020 virtual APSA annual meeting (regardless of which section sponsored the panel) that discusses the intersection of economic inequality and other social inequalities (e.g., racial, ethnic, gender, sexual orientation).
Award Committee: Amber Wichowsky, Marquette University; Jennifer Erkulwater, University of Richmond; Jesse Rhodes, University of Massachusetts Amherst

Recipient: Alice Xu, Harvard University

Title: "Segregation and the Spatial Externalities of Inequality: A Theory of Collateral Cooperation for Public Goods in Cities." Unpublished manuscript presented at the APSA Annual Meeting, 2020.

Kauffman Foundation Award for Best Paper on Entrepreneurship and Inclusion

For the best paper on entrepreneurship and inclusion presented at a panel sponsored by (or co-sponsored by) the Class and Inequality Section at the 2020 virtual APSA annual meeting. Graciously funded by The Ewing Marion Kauffman Foundation.

Award Committee: Daniel Stegmuller, Duke University; Janice Fine, Rutgers University; Simon Weschle, Syracuse University

Recipient: James K. Conran, University of Oregon

Title: "Work Time Regimes and the Comparative Political Economy of the Gender Pay Gap." Unpublished manuscript presented at the APSA Annual Meeting, 2020.

\section{SECTION 46: IDEAS, KNOWLEDGE AND POLITICS}

\section{Best Book Award}

This award recognizes the best recent book on empirical or normative aspects of the causal role of ideas or knowledge claims in politics or government.

Award Committee: Paul M. D. Gunn (Chair), Goldsmith's, University of London; Hélène Landemore, Yale University; Adam B. Lerner, Royal Holloway, University of London

Recipient: Vivien Schmidt, Boston University

Title: Europe's Crisis of Legitimacy. Oxford University Press, 2020.

\section{SECTION 47: AMERICAN POLITICAL THOUGHT}

Best Book in American Political Thought

Winner of The Best Book in American Political Thought Award will be chosen every year by the section council.

Award Committee: Dennis Rasmussen, Syracuse University; Lee Ward, Baylor University; Nora Hanagan, University of North Carolina at Chapel Hill

Recipient: Bob Pepperman Taylor, University of Vermont Title: Lessons From Walden. Notre Dame Press, 2020.

\section{Best Article in American Political Thought}

The winner of The Best Article in American Political Thought Award will be chosen every year by the Section Council from among the articles published in the journal American Political Thought the preceding year.

Award Committee: Steven B. Smith, Yale University; Helena Rosenblatt, The City University of New York; Justin Crowe, Williams College

Recipient: Lucy Williams, Brigham Young University Title: "Blasting Reproach and All-Pervading Light: Frederick Douglass's Aspirational American Exceptionalism." American Political Thought, Summer 2020.

\section{SECTION 48: INTERNATIONAL COLLABORATION}

\section{Best Article Award}

The Best Article Award is given for the best article on international collaboration published in 2020.

Award Committee: Judith L. Goldstein (Chair), Stanford University; Inken Von Borzykowski, University College London; Idean 
Salehyan, University of North Texas

Co-Recipients: Terrance L Chapman, University of Texas at Austin and Stephen Chaudoin, Harvard University

Title: "Public Reactions to International Legal Institutions: The International Criminal Court in a Developing Democracy." Journal of Politics, 82:4.

Co-Recipients: Erin Graham, Drexel University and Alexandria Serdaru, Case Western Reserve University

Title: "Power, Control and the Logic of Substitution in Institutional Design: The Case of International Climate Finance." International Organization, 74, 2020.

\section{Best Book Award}

The Best Book Award is given for the best book on international collaboration published in 2020

Award Committee: Ayse Kaya Orloff (Chair), Swarthmore College; Marina Henke, Hertie School; Chad Rector, Marymount University

Recipients: Allison Carnegie, Columbia University and Austin Carson, University of Chicago

Title: Secrets in Global Governance. Cambridge University Press, 2020.

Honorable Mention: Giovanni Mantilla, Cambridge University

Title: Lawmaking Under Pressure. Cornell University Press, 2020.

\section{Best Dissertation Award}

The Best Dissertation Award is given for the best dissertation on international collaboration for a PhD awarded in 2020.

Award Committee: Soo Yeon Kim (Chair), National University of Singapore; David Doyle, University of Oxford; Rupal Mehta, University of Nebraska-Lincoln

Recipient: Renanah Miles Joyce, Columbia University Title: "Exporting Might and Right Great Power Security Assistance and Developing Militaries."

\section{Distinguished Mentor Award}

The Distinguished Mentor Award is given for excellence in mentoring graduate students and junior faculty in the study of international collaboration.

Award Committee: Carolina Garriga (Chair), University of Essex; Cullen Hendrix, University of Denver; James Raymond Vreeland, Princeton University

Recipient: Kenneth Scheve, Yale University

\section{SECTION 49: MIDDLE EAST AND NORTH AFRICA POLITICS}

\section{Best Book on MENA Politics}

Two awards are given by this committee: One for the best book published in 2020 on MENA Politics, and one for best book on MENA politics by a first-time author.

Award Committee: Lisa Wedeen (Chair), University of Chicago; Nadya Haij, Wellesley College; Peter Krause, Boston College Recipient: Noora Lori, Boston University

Title: Offshore Citizens: Permanent Temporary Status in the Gulf. Cambridge University Press, 2019.

\section{Best MENA Politics APSA Paper}

Award for best paper on MENA Politics presented at the 2020 Annual Meeting.

Award Committee: Mazen Hassan (chair), Cairo University; May Darwich, Birmingham University; Dina Bishara, Cornell University
Recipients: Tugba Bozcaga, Harvard University and Fotini Christia, Massachusetts Institute of Technology

Title: "Imams and Businessmen- Islamist Service Provision in Turkey."

Best Dissertation on MENA Politics

Award for Best Dissertation on MENA Politics Defended in 2020.

Award Committee: Steven Brooke (Chair), University of Wisconsin- Madison; Nadine Sika, American University of Cairo; Bozena Welbourne, Smith College

Recipient: Lillian Frost, Virginia Tech University

Title: "Ambiguous Citizenship: Protracted Refugees and the State in Jordan."

Honorable Mention: Scott Williamson, Bocconi University Title: "The King Can Do No Wrong: Delegation and Blame Under Authoritarian Rule."

\section{Best Article on MENA Politics}

Award for the best article on MENA Politics published in 2020.

Award Committee: Neil Ketchley (Chair), University of Oslo; Kevin Koehler, NATO Defense College; Melani Cammett, Harvard University

Recipient: Max Gallien, University of Sussex

Title: "Informal Institutions and the Regulation of Smuggling in North Africa." Perspectives on Politics.

Recipient: Rich Nielsen, Massachusetts Institute of Technology Title: "The Case of Female Salafi Preachers." American Journal of Political Science.

\section{SECTION 51: EDUCATION POLITICS AND POLICY}

Best Education Politics and Policy Paper

Recognizes the best paper on education politics and/or education policy presented at the previous year's APSA Annual Meeting. Award Committee: Linda White, University of Toronto; Jason Giersch, University of North Carolina at Charlotte; Ben Ross Schneider, Massachusetts Institute of Technology

Recipient: David Lopez, New York University

Title: "The Informational Foundations of Mass Education: State Formation, Legibility, and Centralization Since the 19th Century." Unpublished manuscript presented at the APSA Annual Meeting, 2020.

Best Education Politics and Policy Dissertation Recognizes the best dissertation on education politics and/or education policy presented at the previous year's APSA Annual Meeting.

Award Committee: Sarah Reckhow, Michigan State University; Mneesha Gellman, Emerson College; Vladimir Kogan, Ohio State University

Recipient: Matthew Nelsen, University of Chicago

Title: "Educating for Empowerment: Race, Socialization, and Reimagining Civic Education." PhD Dissertation submitted to Northwestern University in June 2020.

Best Book on Education Politics and Policy Recognizes the best book on education politics and/or education policy published in the previous two years.

Award Committee: Ben Ansell, Oxford University and Diana Owen, Georgetown University

Recipient: Ursula Hackett, Royal Holloway, University of London

Title: America's Voucher Politics: How Elites Learned to Hide the State. Cambridge University Press, 2020. 